MANnheim Research Institute for the ECONomics of Aging

\title{
ON THE FEASIBILITY OF NOTIONAL DEFINED CONTRIBUTION SYSTEMS:
}

\section{The German CASe}

Christina Benita Wilke

165-2008

( mea-Mannheim Research Institute for the Economics of Aging

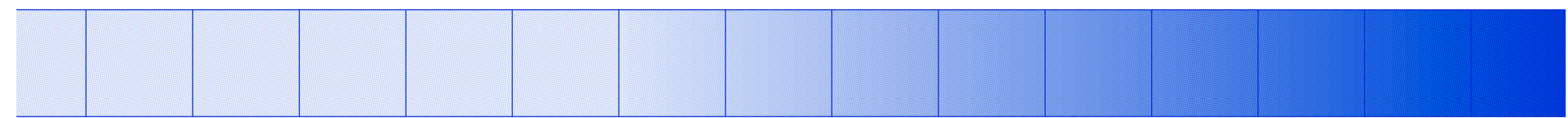

L13, 17_D-68131 Mannheim_Phone +49 621 181-2773/1862_Fax +49 621 181-1863_www.mea.uni-mannheim.de 


\title{
On the feasibility of notional defined contribution systems: The German case
}

\author{
Christina Benita Wilke \\ Mannheim Institute for the Economics of Aging (MEA), Mannheim University
}

\begin{abstract}
Notional defined contribution (NDC) systems have strongly been being debated in the worldwide pension literature in the past years. This paper deals with the feasibility of such NDC systems. The focus is on the German case, where the recent 2004 pension reform introduced a so-called sustainability factor, that de facto incorporates some crucial characteristics of an NDC system into the public pension system, but maintains the traditional benefit indexation formula approach. The paper analyzes the effects a hypothetical introduction of an NDC system would have on the financial situation of the German PAYG system.

It is found that a genuine NDC system would be feasible in the sense that it would be financially possible and would achieve gross pension levels above, equal or only slightly below those that can be forecasted for the standard pensioner under the present German pension system. However, it is shown that an NDC system would require large buffer funds which are currently not available. Furthermore, the distribution of pension income among cohorts and across time would be very different and may be hard to motivate from a political perspective.

Altogether, it becomes clear that an NDC system cannot solve the demographic problems but simply copes with them in a different way than conventional PAYG systems. Thus, it does not replace the necessity to supplement the public pension system by a funded second and third private pillar in order to prepare for the future demographic changes.
\end{abstract}

\author{
Address: \\ Christina Benita Wilke \\ Research Fellow \\ Mannheim Research Institute for the Economics of Aging \\ (MEA), Department of Economics \\ Mannheim University \\ L13,17 \\ D-68131 Mannheim, Germany \\ E-mail: wilke@mea.uni-mannheim.de
}

Acknowledgements: I am grateful for many helpful comments by Axel Börsch-Supan, Agar Brugiavini and Anette Reil-Held. Thanks are also due to the German National Science Foundation (DFG), the Gesamtverband der deutschen Versicherungswirtschaft (GDV) and the European Research Training Network (RTN) for their financial support. The usual disclaimer applies. 


\section{On the economic feasibility of notional defined con- tribution systems: The German case}

By Christina Benita Wilke

\section{Introduction}

As in many other industrialized countries, the public pay-as-you-go (PAYG) pension system in Germany is in great financial distress. On the one hand, expenditures rise as pensions have to be financed for longer pension periods due to continuous increases in life expectancy and an early retirement age induced by generous early retirement options. On the other hand, revenues stay behind as younger, working cohorts become smaller thus accounting for fewer contributors. This situation will deteriorate even further when the baby boom generation will begin to retire around 2015.

One approach of how to cope with these problems are notional defined contribution (NDC) systems that have strongly been being debated in the worldwide pension literature in the past years. They can be regarded as the new wave of pension reform following the wave of pre-funded systems that were promoted by the World Bank in the mid-eighties. ${ }^{1}$ In contrast to these pre-funded systems, the NDC approach does not require a transition to a fully funded system but can be regarded as a complementary strategy that aims at restructuring the first, PAYG financed pillar. It thus preserves existing PAYG systems, offering a reform alternative to those countries that wish to keep a substantial public PAYG pillar, as it is the case in Germany. Still, the conversion of an existing PAYG pillar to an NDC system does not exclude a partial transition to pre-funding. Indeed, both reform options may complement each other in a multi-pillar approach.

The NDC approach is based on two main ideas: (1) Intergenerational redistribution within the PAYG pillar is to be minimized by establishing a set of individual accounts where contribution payments are recorded and from which individual pension benefits can be directly derived at the time of retirement, accounting for individual life expectancy. (2) In order to ensure the long-run sustainability of the PAYG system, demographic and labour market changes are directly reflected in the interest accrued on the accumulated contribution payments on the individual account.

\footnotetext{
${ }^{1}$ See World Bank (1994).
} 
This paper looks at whether such a NDC system would be an economically feasible reform alternative for the German public pension system. In fact, the German public pension system already bears some resemblance to an NDC system. ${ }^{2}$ Thanks to its point system, which goes back to the introduction of the PAYG system in 1957, the German public pension system is based on a similar concept of individual accounts. Furthermore, the actuarial adjustments depending on the time of retirement entry, that have been phased in following the 1992 and 1999 reforms, mimic the automatic adjustment to changes in life expectancy in an NDC system. Finally, the sustainability factor proposed by the Rürup Commission and implemented with the 2004 pension reform, introduces a self-stabilizing feedback mechanism that responds to changes in demography and labor market development, similar to the one in an NDC system. However, there remain crucial differences between the two systems.

An NDC system, in principle, could have some valuable advantages over the present German system. ${ }^{3}$ First, the NDC system provides great flexibility regarding the choice of the retirement age, which could set an end to the ongoing eligibility discussion in the German PAYG system. A second advantage would be the enhanced transparency of an NDC system. This could be extremely helpful for Germany, where the public pension system is composed of a very complicated set of numerous regulations, which obscure the actual size of pension benefits that can be expected from the system as well as the need for private old-age pension. Moreover, increased transparency might help to re-establish some of the credibility that the German PAYG system has lost over the course of the repeated discretionary interventions. Another advantage would be that such discretionary interventions would no longer be easy in an NDC system. ${ }^{4}$

Thus, a conversion of the German PAYG system to an NDC system in principle could bring about some crucial benefits. Moreover, such a conversion should be easily possible due to the existing analogies between the two systems. This paper analyzes the effects a hypothetical introduction of an NDC system would have on the financial situation of the German PAYG system. The paper is structured as follows: Section 2 gives an introduction into the NDC concept. Section 3 then focuses on the current situation in Germany. It presents the German pension system as it is today and provides an overview of the German past and projected demographic and labour market development as well as of the present system's future prospective. Section 4

\footnotetext{
${ }^{2}$ Siehe Börsch-Supan (2004).

${ }^{3}$ These advantages are partly due to the individualization achieved by the underlying concept of individual accounts. For a general discussion of this concept, see Holzmann and Palacios (2001).

${ }^{4}$ These are only some selected aspects of NDC systems. A thorough discussion of advantages and disadvantages of NDC systems can be found in Barr (2003).
} 
presents a thorough simulation and sensitivity analysis on the effects such a hypothetical introduction would have on pension levels and the budget of the Germany pension insurance. Section 5 concludes.

\section{Notional defined contribution systems}

The NDC concept was first designed in Sweden, where the system passed legislation in 1994, and was introduced in 2001 with a 16 years transition period. ${ }^{5}$ However, it can be argued that the basic underlying principles of the NDC system are already present in earlier concepts likes the one presented by Buchanan in $1968^{6}$ or the German and French point systems respectively ${ }^{7}$. Soon after the system had been legislated in Sweden, Latvia and Poland took up the concept and integrated it into their ongoing pension reform processes. ${ }^{8}$ They thus became the first countries to introduce an NDC system for the first pillar in $1995 .{ }^{9}$ At the same time, Italy also legislated an NDC approach for its first pillar in the context of the so-called Dini reform. However, the system will not become effective before 2040, due to an extremely long transition period. ${ }^{10}$ Apart from these European countries, NDC systems have also been introduced in Brazil and the Kyrgyz republic. ${ }^{11}$

In the literature, NDC systems are not undisputed. While they are perceived quite positively by those who experienced and accompanied their introduction (e.g. Palmer, 2000; Chloń, Góra and Rutkowski, 1999), they receive some serious criticism from other economists that observe the process from the outside (e.g. Disney, 1999; Valdés-Prieto, 2000).

This section gives a brief introduction to the NDC system approach. The basic concept is explained in section 2.1. Section 2.2 provides a mathematical description. Section 2.3 discusses some selected aspects of system design and system behaviour.

\footnotetext{
${ }^{5}$ See Sundén (2000) for a brief overview of the Swedish NDC system. A thorough description of the system can be found in Palmer (2000).

${ }^{6}$ See Valdés-Prieto (2000).

${ }^{7}$ See Disney (1999) and Valdés-Prieto (2000).

${ }^{8}$ For a description of the Latvian pension reform see Fox and Palmer (1999), for a description of the Polish reform see Chloń, Góra and Rutkowski (1999).

${ }^{9}$ A first assessment on the Polish pension reform can be found in Chloń and Góra (2003).

${ }^{10}$ See Franco and Sartor (2003) and Brugiavini and Galasso (2004) for an evaluation of the Ital ian pension reform process.

${ }^{11}$ See Brooks and Weaver (2003) for a description of the NDC system in Brazil and Palmer (2003) for a brief description of the NDC system in the Kyrgyz republic.
} 


\subsection{Basic concept}

The NDC system is a PAYG system that in principle is based on a defined contribution (DC) instead of the conventional defined benefit (DB) approach that has been the basis for most PAYG systems until recently.

Defined benefit (DB). In the conventional DB based PAYG system the size of pension benefits is annually determined via the so-called benefit indexation formula such that a predefined desirable pension level for a reference pensioner ${ }^{12}$ can be maintained. Pension benefits thus are not directly linked to the amount of previously paid contributions but depend to a large extent on the shape of the benefit indexation formula. In order to ensure an annually balanced budget, the system's contribution rate is raised accordingly if estimated revenues under the present rate are not sufficient to cover arising pension claims. Given the increasing demographic and economic pressures, this has led to seemingly ever rising contribution rates in many countries in the past decade.

Defined contribution (DC). The DC approach, commonly used in the capital market for private pension arrangements, derives pension benefits directly from the amount of previously paid contributions by converting the accrued pension wealth into a life-long pension annuity. This happens only once, at the time of retirement. The contribution rate is hereby set exogenously. ${ }^{13}$

An NDC system combines this DC approach with the basics of a PAYG system. Contributions to the pension system are recorded on individual accounts so that subsequent pension benefits can be calculated as a life-long annuity on the basis of the accumulated capital stock at the end of the working period. However, since contributions in a PAYG system are needed to finance current pension expenditures, they can only notionally be recorded on the accounts, without any real money transfer, which is why the system is referred to as a notional defined contribution (NDC) system. There is no annual budget constraint in this system as it is the case for conventional

\footnotetext{
${ }^{12}$ In Germany, the reference pensioner is the so-called standard pensioner who worked for 45 years, always earned the average wage and retired at the statutory retirement age of 65. In the German point system he is thus credited 45 earnings points. The earnings points system will be explained in detail in section 3.1. More information on the concept of the standard pensioner and the measurement of pension levels in Germany is provided in the Appendix.

${ }^{13}$ Note that the distinction between defined benefit and defined contribution systems can be made from different perspectives. In the range of PAYG systems, a defined contribution approach can also refer to a PAYG system, where the contribution rate is exogenous while benefits are determined endogenously under the annual budget constraint. See e.g. Lindbeck and Persson (2003). However, for the purpose of this paper, the notion "defined contribution" refers solely to the annuity mechanism used on capital markets that establishes a tight link between contribution payments and pension benefits.
} 
PAYG systems. The contribution rate enters exogenously and thus can be held constant or follow a predetermined, desired path.

\subsection{Mathematical description}

As it was explained above, in an NDC based PAYG system annual contributions are accumulated on notional individual accounts (contribution phase) so that, at the time of retirement, a life-long pension annuity can be calculated from the accrued notional capital (pension phase).

Contribution phase. Given the annual gross wage income $Y_{i, t}$ of an individual $i$, contributions to the pension system $C_{i, t}$ in year $t$ by the individual $i$ can be determined as follows:

$$
C_{i, t}=\tau_{t} Y_{i, t}
$$

The contribution rate $\tau_{t}$ can either be fixed $\left(\tau_{t=} \tau\right)$ or follow a predetermined path, since the system is no longer subject to an annual budget constraint as under the conventional PAYG system approach.

The individual's working life covers the period from A to B, where the first working year is $\mathrm{t}=1=\mathrm{A}$ and the last working year is $\mathrm{t}=\mathrm{B}$ (e.g. 40 years). At the time the individual retires (at time $B$ ), its accumulated notional pension wealth $P W_{i, B}$ amounts to:

$$
P W_{i, B}=\sum_{t=A}^{B-1}\left(C_{i, t} \prod_{s=t}^{B-1}\left(1+r_{t}\right)\right)+\tau_{B} Y_{i, B}
$$

The chosen interest rates $r_{t}$ are crucial for the calculation. This issue will be discussed in more detail below.

Pension phase. Pension benefits $P_{i, t}$ for an individual $i$ in year $t$ can be calculated from the accrued notional pension wealth $P W_{i, B}$ as an annuity:

$$
P_{i, t}=\frac{P W_{i, B}}{G}
$$

Most simply, the annuitization divisor $G^{14}$ can be set equal to remaining life expectancy at retirement $n_{B}$ :

$$
G=n_{B}
$$

Subsequent changes in life expectancy after the time of retirement do have no effects on the size of pension benefits. However, equation 4 only holds if no interest is

\footnotetext{
${ }^{14}$ In the literature this annuity factor is also referred to as G-value. See e.g. Chłoń and Góra (2003).
} 
granted on the remaining capital on the notional account at any time $t>B$ and if pension benefits are assumed to be equal for all years $t$. Loosening the first restriction and assuming that some form of (constant) interest $r^{*}$ is accrued on the remaining notional capital, the annuity divisor $G$ changes as follows: ${ }^{15}$

$$
G=\left(1+r^{*}\right)^{1-n_{B}} \frac{\left(1+r^{*}\right)^{n_{B}}-1}{\left(1+r^{*}\right)-1} .
$$

In order to calculate this annuity, the notional interest rate $r$ has to be defined a priori and therefore can only depend on estimated future values of $r^{*} \cdot{ }^{16}$ Again, the interest rate chosen is crucial.

If the second restriction is also lifted, pension benefits may rise over the course of the retirement period, i.e. they can be indexed to a certain reference rate. This can be captured by introducing a factor $\delta$ into the formula of the annuity divisor $G$ :

$$
G=\left(1+r^{*}\right) \frac{\left(\frac{1+\delta}{1+r^{*}}\right)^{n_{B}}-1}{\delta-r^{*}} \quad \text { where } P_{i, t}=(1+\delta)^{t-B-1} P_{i, B+1}
$$

For simplicity, $\delta$ is assumed to be a constant percentage $(0<\delta<1)$. Possible indexing factors will be discussed in the following section.

\subsection{System design and system behaviour}

If the contribution rate to the pension system is fixed and pension benefits are determined from accrued pension wealth according to the annuity mechanism, how can the system be stabilized? The answer to this question refers to the chosen system design and the corresponding behaviour effects.

System design. There are numerous design features for an NDC system. ${ }^{17}$ As it was already pointed out in the previous section, the interest rate $r_{t}$ that is accrued on the accumulated contributions and the parameters $n_{B}, r^{*}$ and $\delta$ that are applicable for the calculation of the life-long pension annuity are crucial to the essence of the system. The same applies for the choice of the contribution rate. However, this is an issue that is highly country-specific and will therefore only be dealt with in the context of the sensitivity analysis in section 4.4. The other aspects will be discussed below.

\footnotetext{
${ }^{15}$ It is assumed that pension benefits are paid in advance, at the beginning of the year or month respectively.

${ }^{16}$ It therefore is sufficient to assume a constant interest rate $r$ since even if changes in $r$ are expected in the future, it is reasonable to take an average value of $r$ for the calculation of the pension annuity.

${ }^{17}$ See Palmer (2003) for a comprehensive list and discussion of possible design features.
} 
Interest rate on contributions

Börsch-Supan (2004) points out that from a macro-economic point of view the NDC system can only be sustainable if the chosen interest rate $r_{t}$ is the internal rate of return of the PAYG system, i.e. the growth rate of the contribution bill. This internal rate of return of the system can be measured as the change in the number of contributors and their labour productivity growth. ${ }^{18}$ In this case changes in demography, employment and productivity are accurately reflected in the rate of return. So far, this approach has not been implemented in any of the countries that introduced an NDC system, though. In Latvia and Poland contributions are granted interest according to the ex-post growth rate of the covered wage bill, thereby only accounting for changes in productivity and neglecting changes in the number of contributors. Italy follows a similar approach by using a moving average of nominal GDP growth ${ }^{19}$ as an index. As long as it is assumed that the productivity growth of the economy is closely mirrored by the development of earnings, these approaches are basically identical. Sweden indexes contributions to a moving average of ex-post per capita wage growth ${ }^{20}$, but established an automatic adjustment mechanism in case the financial stability of the system is threatened. ${ }^{21}$ Brazil in turn does not grant any interest on contributions. $^{22}$

\section{Pension annuity}

As was explained in section 2.2, the life-long pension $P_{i, t}$ is derived on the basis of the accumulated pension wealth $P W_{i, B}$ considering three parameters:

- the remaining life expectancy $n_{B}$ at the time of retirement,

- the interest rate $r^{*}$ that is accrued on the notional pension capital and

- the indexing factor $\delta$ that allows for increases in pension benefits over the retirement period.

The remaining life expectancy $n_{B}$ at the time of retirement differs for men and women, but in general unisex survival rates are applied, so that the annuity is equal

\footnotetext{
${ }^{18}$ This corresponds to the Samuelson-Aaron condition, where the internal rate of the system is given by $\mathrm{n}+\mathrm{g}$ with $\mathrm{n}=$ population and $\mathrm{g}=$ productivity growth (Samuelson, 1958 and Aaron, 1966). A description of possible calculation methods of the rate of return of PAYG systems can be found in Settergren (2003). For an evaluation of the internal rate of the German PAYG system, see Schnabel (1998).

${ }^{19}$ The moving average is computed over 5 years of GDP in order to smooth business cycle effects.

${ }^{20}$ The moving average is computed over 3 years of wage growth.

${ }^{21}$ For a thorough description of the automatic balancing mechanism, see Settergren (2001).

${ }^{22}$ For a description of the so-called "accumulation factor" applied in Brazil, see Brooks and Weaver (2003).
} 
for men and women. ${ }^{23}$ In order to obtain the appropriate life expectancy data, cohort specific life tables must be available. So far, cohort life tables are still not freely disposable in many countries, which creates potential sources of political manipulation.

The choice of the interest rate $r^{*}$ in principle follows the same rule as for the interest rate $r_{t}$ on contributions. However, in order to calculate the annuity, the applicable interest rate $r^{*}$ has to be defined a priori and therefore can only depend on estimated future values and not on actual ex-post values as in the case of the interest rate $r_{t}$ on contributions. In Sweden, a real rate of return of $1,6 \%$ is used, which is in accordance with both the projected long-run rate of return as well as the economy's expected real growth rate.

The decision whether benefits shall be indexed to a reference rate over the course of the retirement period or not has to be made at the time of retirement $(t=B)$ when the life-long pension $\mathrm{P}_{\mathrm{i}, \mathrm{t}}$ is calculated. Basically, there are three options as to how to set the indexing factor $\delta$ :

$\circ \delta=0$ means that pension benefits during the retirement period remain constant, but only in nominal terms. ${ }^{24}$

○ $\delta=\pi$ indexes pension benefits to the (projected or actual) inflation rate $\pi$, so that benefits remain constant in real terms. This approach is used in Sweden.

○ $\delta=\mathrm{g}$ indexes pension benefits to the (projected or actual) annual rise in nominal wages or productivity respectively, so that pension benefits remain a constant fraction of wages.

The fact that the computation of the pension annuity heavily depends on estimated values introduces a certain level of uncertainty at room for political discretion. If benefits are indexed to actual rates and projected rates are higher, pension benefits become cheaper than initially calculated. Whereas, if pensioners live longer than estimated, pension expenditures become more expensive than initially calculated and if the ex-post increase of the interest rate $r^{*}$ is lower (higher) than the estimated increase, pension benefits are harder (easier) to finance with the available contribution revenues. However, these are uncertainties that every private insurance business has to cope with.

\footnotetext{
${ }^{23}$ This e.g. is the case in Sweden. In contrast, private pension funds on the capital market usually apply sex specific survival rates.

${ }^{24}$ In this case, equation 5 instead of equation 6 is then applied for the calculation of the annuity.
} 
System behaviour. Although the NDC system maintains the PAYG system approach, it behaves quite differently compared to conventional PAYG systems regarding both the development of pension levels and the pension insurance's budget.

\section{Cohort-specific and total cohort pension levels}

In contrast to conventional PAYG pension systems, where pension levels are annually readjusted by the benefit indexation formula ${ }^{25}$ and where this readjustment equally affects the size of benefits of all pensioners, pension levels in the NDC system are cohort-specific. In order to reflect the development of pension levels across as well as for specific cohorts, an annual universal pension level can thus no longer be applied. Instead, two separate measures have to be considered. Pension levels for specific cohorts can be illustrated by displaying for each year $t$ only the pension level of the cohort whose respective reference pensioner retires in that year. ${ }^{26}$ This will be referred to as the cohort-specific pension level at retirement in the remainder of this paper. An annual pension level reflecting the situation across reference pensioners of all cohorts can then be calculated as the average of reference pensions over all cohorts weighted with the respective cohort sizes. This will be referred to as the total cohort pension level in the remainder of this paper.

\section{Short-term and long-term budget effects}

In each year $t$ the public pension system receives revenues $R_{t}$ in form of contributions by the labour force and pays expenditures $E_{t}$ in form of pension benefit payments to the pensioners:

$$
\begin{aligned}
& R_{t}=\sum_{i=1}^{N_{t}} \tau_{t} Y_{i, t} \text { and } E_{t}=\sum_{j=1}^{M_{t}} P_{i, t} \\
& \text { with } \quad N_{t} \ldots \text { size of labour force in year } t \text { and } \\
& \\
& M_{t} \ldots \text { size of stock of pensioners in year } t .
\end{aligned}
$$

For the short term, the crucial question is whether revenues $R_{t}$ match expenditures $E_{t}$, i.e. whether the annual pension budget is balanced. In conventional PAYG systems, the contribution rate to the pension system $\tau_{t}$ is recalculated each year such that estimated revenues $R_{t}^{*}$ equal estimated expenditures $E_{t}^{*}$. Alternatively, the contribution rate $\tau_{t}$ can be fixed $\left(\tau_{t}=\tau\right)$ so that pension levels have to be adjusted in order to bal-

\footnotetext{
${ }^{25}$ See section 3.1 for an explanation of the current German benefit indexation formula.

${ }^{26}$ In Germany, the reference pensioner is the so-called standard pensioner that retires at age 65 . Thus the cohort-specific pension level for e.g. the year 2005 would correspond to the pension level of a standard pensioner of the 1940 cohort. For the concept of the German standard pensioner, see also footnote 12 .
} 
ance the budget. In each case, the annual budget balance can be achieved by the appropriate adjustments. In an NDC system this annual (short-term) budget balance is no longer assured. The reason is that the contribution rate is given, while at the same time pension benefits cannot be adjusted freely since their value is no longer recalculated annually but instead is determined only once at the time of retirement as a lifelong pension. In the short-run, there are thus no possibilities to balance the system unless ex-post adjustments are made to the applicable interest rate $r^{*}$ or the indexing factor $\delta$.

As a result, the existence of an appropriate reserve fund is crucial for the introduction of an NDC system. Sweden for example disposes of a large reserve fund that amounts to about 4 years of expenditures. ${ }^{27}$ In contrast, the German system's reserve fund only amounts to several days. ${ }^{28}$

Although NDC systems cannot ensure the short-term balance of the pension budget, one of their main characteristics is said to be the long-term balance of the budget. In other words, NDC systems are supposed to make the pension system financially sustainable. ${ }^{29}$ This is disputed in the pension literature, though. ${ }^{30}$ In principle, as it was already mentioned above, this only holds if the system operates with its internal rate of return. In this case, demographic and labour market changes are directly reflected in pension benefits, allowing the systems restoration from demographic or economic shocks and thereby ensuring a balanced system in the long run. $^{31}$

In general, short- and long-term balance cannot coexist in an NDC system. If e.g. the annual budget constraint was to be maintained within an NDC framework, this would mean that the contribution rate could no longer be predetermined but would instead result as a residual from the annual budget calculation as it is the case in conventional PAYG systems. This, however, would affect subsequent pension levels. Thus, depending on the country-specific case, pension expenditures as well as contribution rates of such a system might just explode.

\footnotetext{
${ }^{27}$ See Settergren (2001), p.4.

${ }^{28}$ In 2000, the buffer fund of the German pension system amounted to 14 billion Euros in relation to total annual system expenditures of 214 billion Euros (Verband Deutscher Rentenversicherungsträger, 2002). Under the 2004 reform, this reserve was turned into a so-called sustainability reserve that amounts to 0.2 to 1.5 of monthly pension expenditures and is supposed to be built up in 'good' years and is melted down as soon as the upper 1.5 limit is reached.

${ }^{29}$ Financial stability in this context can be defined as "the ability of a pension plan to adjust to financial shocks without legislative intervention." (Valdés-Prieto, 2000)

${ }^{30}$ See e.g. Valdés-Prieto (2000) for a mathematical analysis of the system's long-run effects.

${ }^{31}$ On the issue of financial sustainability see also Gronchi and Aprile (1998).
} 


\section{The current situation of the German pension system}

How would an NDC system fit into the existing landscape of German social policy? As was mentioned in the introduction, the German PAYG system already shows some similarities to an NDC system. Section 3.1 briefly describes the basic features of the German pension system as it is today and points out to what extent these features bear resemblance to those in an NDC system. Section 3.2 then takes a look at the past and projected future demographic and labour market development in Germany. Based on this German-specific demographic and labour market background, a forecast of the (present) German PAYG system is presented in section 3.3.

\subsection{Status quo}

The German pension system consists of three pillars. The first pillar comprises the publicly financed PAYG system, which is mandatory for all private and public sector employees. Company pension schemes - which companies must offer to their employees since the Riester reform in 2001 - form the second pillar. The third pillar comprises private pension arrangements. In contrast to the first one, the second and third pillar are funded systems. The introduction of an NDC system in Germany would focus on a reform of the first pillar, while the second and third pillar would only be indirectly affected. This section therefore concentrates on the principles of the PAYG system and on its similarities to an NDC system.

Basic principles. In Germany, the pension benefits $P_{i, t}$ of an individual pensioner $i$ at time $t$ are determined according to the following formula:

$$
P_{i, t}=E P_{i, B} \times A A_{i} \times P V_{t}
$$

with $E P_{i, B} \ldots$ sum of personal earnings points at retirement $(t=B)$, $A A_{i} \ldots$ individual actuarial adjustments for early/ late retirement and $P V_{t} \ldots$ current pension value at time $t$.

This formula can be split into an individual component $\left(E P_{i, B} \times A A_{i}\right)$, which is determined once at the time of retirement, and a universal component $\left(P V_{t}\right)$, which is equal for all pensioners and is adjusted on an annual basis according to the benefit indexation formula. Each of the components will be explained in the following.

The benefit indexation formula. As in any conventional PAYG system, the German public pension system is based on a DB approach where the value of the individual pension is annually readjusted according to the benefit indexation formula. This DB based approach has been lately shifted into the direction of a more contribu- 
tion rate oriented approach ${ }^{32}$ : the Riester reform set an upper economically and politically tolerable limit of the contribution rate. ${ }^{33}$ As a consequence, the benefit indexation formula must now be designed such that the contribution rate rises only within the permitted range if future discretionary measures shall be prevented.

The Riester benefit indexation formula tried to achieve the set contribution rate goals but was shown to be insufficient under reasonable demography and labour market projections by the Rürup Commission in 2003. ${ }^{34}$ The Rürup Commission thus proposed to extend the Riester formula by a sustainability factor which is supposed to stabilize the system by directly accounting for changes in the system dependency ratio, i.e. the ratio of pensioners to contributors. The factor is part of the 2004 pension reform and passed the Lower House of German Parliament in March 2004. Simplified, the new benefit indexation formula can be written as follows: ${ }^{35}$

$$
P V_{t}=P V_{t-1} \frac{Y_{A v g, t-1}}{Y_{A v g, t-2}}\left[1+\frac{1}{4}\left(1-\frac{S D R_{t-1}}{S D R_{t-2}}\right)\right]
$$

with $\quad Y_{\text {Avg }} \quad$... average gross (covered) wages and SDR ... system dependency ratio.

\section{Close links of the German benefit indexation formula to an NDC system}

The sustainability factor introduces a mechanism similar to the long-run sustainability of an NDC system that uses the internal rate of return. As in such an NDC system, pension benefits are adjusted downwards once the system dependency ratio worsens. However, in contrast to the NDC system, these adjustments affect all pensioner cohorts alike. Another difference is that changes in the benefit indexation formula are politically more easily possible than changes to the size of pension benefits in the NDC system, where pensions are directly attributable to the individual pensioner. Such discretionary interventions of course are not desirable but provide a tempting policy option to short-term oriented politicians. In fact, since the introduction of the sustainability factor in 2004, several discretionary interventions have already been made.

\footnotetext{
${ }^{32}$ Note that the term "defined contribution" deliberately is not used here since it is the other concept of a defined contribution rate in a PAYG system that restricts the development of pension levels that is meant here. Recall footnote 13, where the distinction between these two alternative concepts was explained.

${ }^{33}$ It was decided that the contribution rate should be kept under 20\% until 2020 and $22 \%$ until 2030 .

${ }^{34}$ For a description of the Riester formula and its effects on the future development of contribution rates and pension levels, see Börsch-Supan and Wilke (2004).

${ }^{35}$ The formula is simplified because the so-called Riester staircase is neglected and the definition of the income base is more complex. Refer to Börsch-Supan, Reil-Held and Wilke (2003) for a thorough description of the formula and its impact on the pension system.
} 
The point system. In Germany, the point system dates back until 1957, when the PAYG system was introduced. During their working life, contributors are granted personal earnings points $E P_{i, t}$ according to the proportion of their individual income $Y_{i, t}$ to the average income $Y_{A v g, t}$ in a year $t$ :

$$
\text { (10) } E P_{i, t}=\frac{Y_{i, t}}{Y_{A v g, t}} \text {. }
$$

At the end of their working life, contributors have accumulated a certain amount of earnings points $E P_{i, B}$ depending on their respective earnings history:

$$
\text { (11) } E P_{i, B}=\sum_{t=A}^{B} E P_{i, t} \text {. }
$$

The amount of earnings points determines the size of the pension (see equation 8).

\section{Close links of the German point system to an NDC system}

Point-based systems, as they are also present in France, can be regarded as an indirect source of the NDC approach. ${ }^{36}$ There is an analogy of accumulated earnings points in the German and currency-based contributions in an NDC system:

- $\quad$ Both relate to the entire working life (in contrast to PAYG systems, where only some selected years of the earnings history are considered).

- $\quad$ Redistributive features (e.g. special acknowledgement for child bearing) can be easily embodied in both systems by a transfer of additional earnings points/ notional contributions by the pension insurance.

The German earnings point system however differs in the following aspects:

- At a fixed contribution rate, all earnings points of an individual count equally while in the NDC system equal contributions in percent of salary are valued higher in earlier periods of the working life due to compound interest.

- At a rising contribution rate, earnings points count equally but in fact are cheaper for earlier contributions. In the NDC system, later earnings may overweigh earlier contributions despite of compound interest.

Actuarial adjustments. Adjustments of benefits to retirement age $\left(A A_{i}\right)$ for early and late retirement entry respectively were introduced in Germany with the 1992

\footnotetext{
${ }^{36}$ See Disney (1999) and Valdés-Prieto (2000).
} 
pension reform and have been phased in since $1997 .{ }^{37} 0.3 \%$ are deducted from pension benefits for every month an individual retires before and $0.5 \%$ are granted for every month an individual retires after the statutory retirement age of 65 . These adjustments shall prevent that people actually gain from early retirement and receive the same pension as later retirees but for longer pension periods. Whether these adjustments are also neutral in terms of labour supply (dis)incentives, however, is highly disputed in the literature. ${ }^{38}$

\section{Close links of the German actuarial adjustments to an NDC system}

In an NDC system, such adjustments are implicit. Since the individual pension is calculated as an annuity taking into account the remaining life expectancy at the time of retirement, the system is automatically actuarially neutral. Thus, in contrast to the German system, no discretionary adjustments are necessary, which avoids potential sources of manipulation. Moreover, while the current German system needs to set a statutory retirement age, the retirement age in an NDC system can be flexible. ${ }^{39}$ In addition, changes in life expectancy have a direct impact on pension benefits in an NDC system ${ }^{40}$ while in the German system they can only be accounted for via unpopular moves in the statutory retirement age.

\subsection{Demography and labour force - past developments and future challenges}

As was mentioned earlier, whether the introduction of an NDC system poses a reasonable reform option for Germany or not depends to a great extent on the past and estimated future development of the demography and the labour market. This section briefly depicts the German situation in this regard. The following future projections of the demographic and labour market development correspond to the projections used by the Rürup Commission for its reform proposal in August 2003. ${ }^{41}$ The same projections form the basis for the simulation analysis in section 4.

Demographic development. The process of population aging is by now a wellknown phenomenon in the industrial world. It originates from constant increases in

\footnotetext{
${ }^{37}$ Refer to Berkel and Börsch-Supan (2003) for details of the transition process.

${ }^{38}$ See Ohsmann, Stolz and Thiede (2003) who justify the current rates, versus Börsch-Supan (2000) who argues they should be higher. The German Reform Commission on the Sustainability of the Social Security Systems (2003) takes a neutral view.

${ }^{39}$ In practice, a minimum retirement age is recommended as soon as some form of guaranteed pension is provided that may create labour supply disincentives. In Sweden, the minimum retirement age is 61 .

40 At least to the extent they can be projected at the time of retirement when the pension is calculated.

${ }^{41}$ See German Commission on the Sustainability of the Social Security Systems (2003).
} 
longevity and declining birth rates. The effects on the size and age structure of the German population are illustrated in Figure 1.

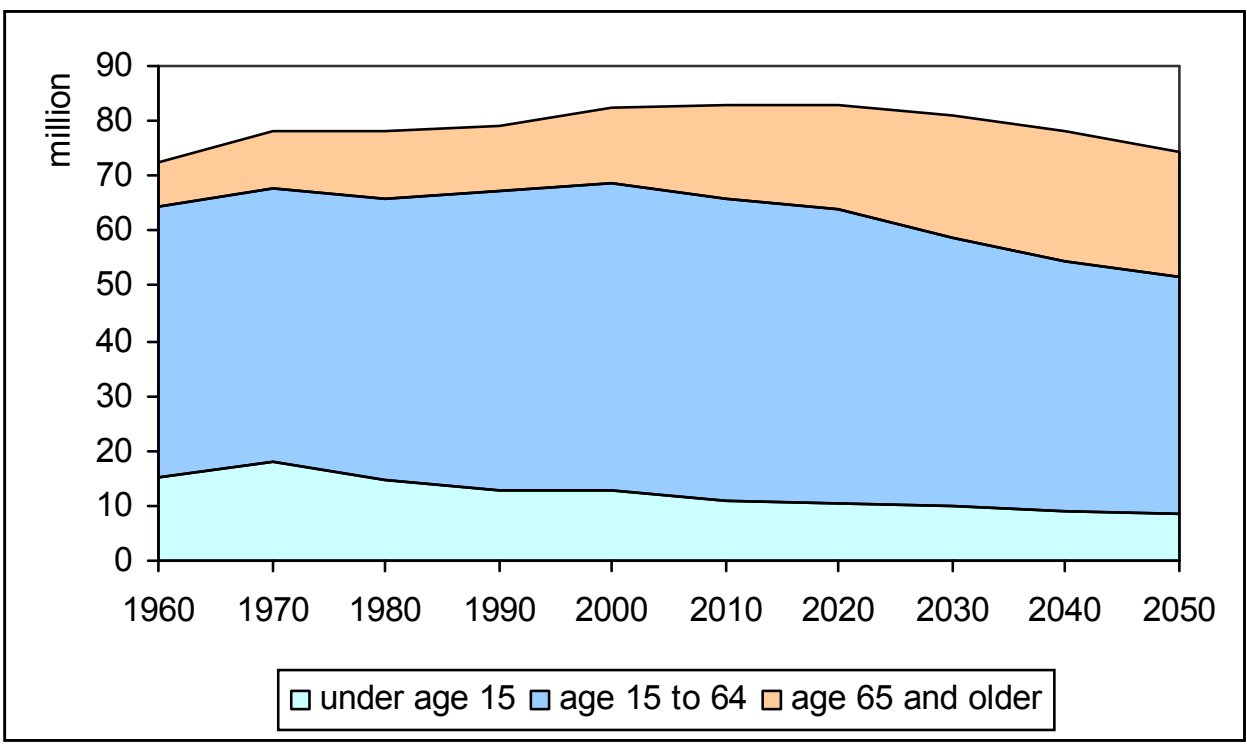

Figure 1: Size AND AGE STRUCTURE OF THE GERMAN POPULATION FROM 1960 TO 2050

Source: German statistical office for data until 2000 and the Reform Commission on the Sustainability of the Social Security Systems for data projections until 2050.

In Germany, this problem becomes particularly severe as a strong baby boom in the late 1950s and early 1960s was directly followed by a baby bust in the 1970s. This led to a large peak in the size of cohorts over time (see Figure 2).

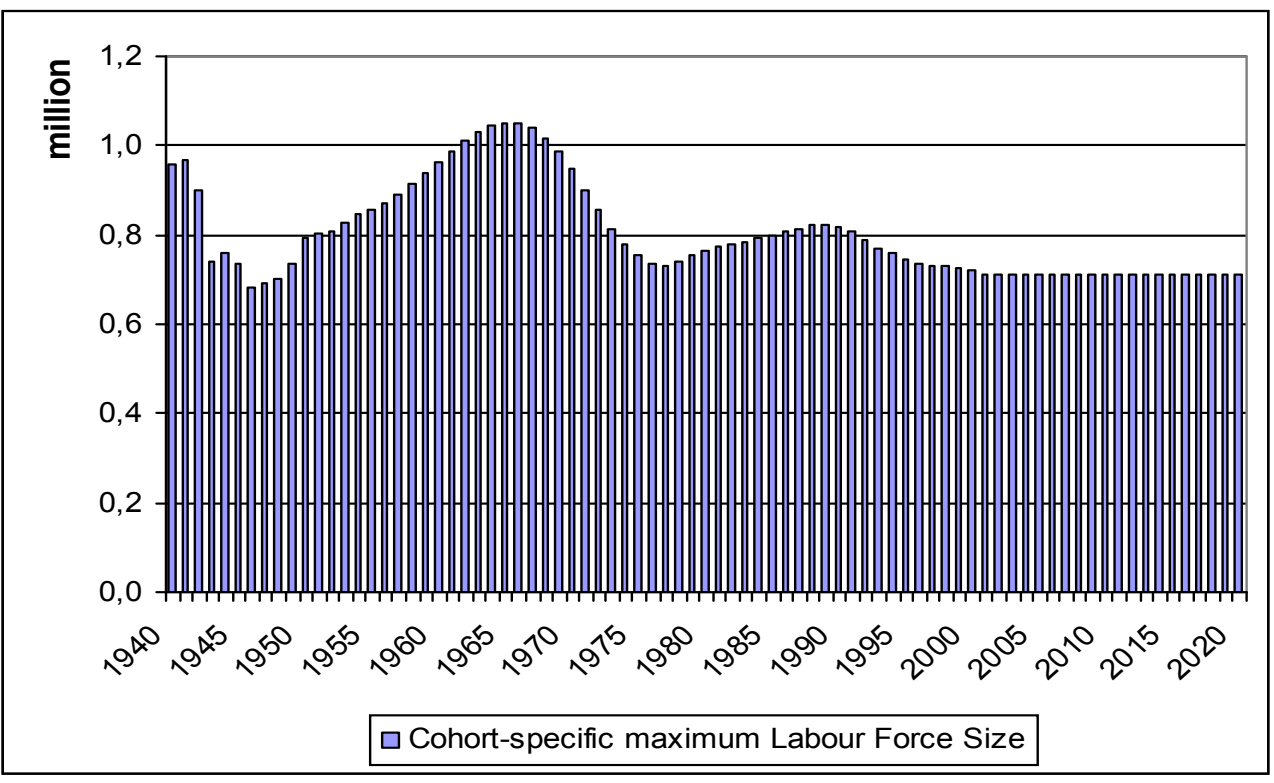

FIGURE 2: MAXIMUM LABOUR FORCE SIZE FOR COHORTS FROM 1940 TO 2020

Source: Author's computations based on data provided by the German statistical office and by the Reform Commission on the Sustainability of the Social Security Systems. 
This poses problems to a PAYG based pension system once the large cohorts enter into retirement around 2015 and have to be financed by the smaller younger cohorts. This development can be illustrated by the change in the old-age-dependency ratio (OADR), which is the ratio of the population at age 65 and older to the working age population. ${ }^{42}$ Figure 3 shows the change in the OADR for Germany with (OADR 15) and without the age group of 15 to 19 year olds (OADR 20). It can be seen that the ratio will almost double over the next fifty years.

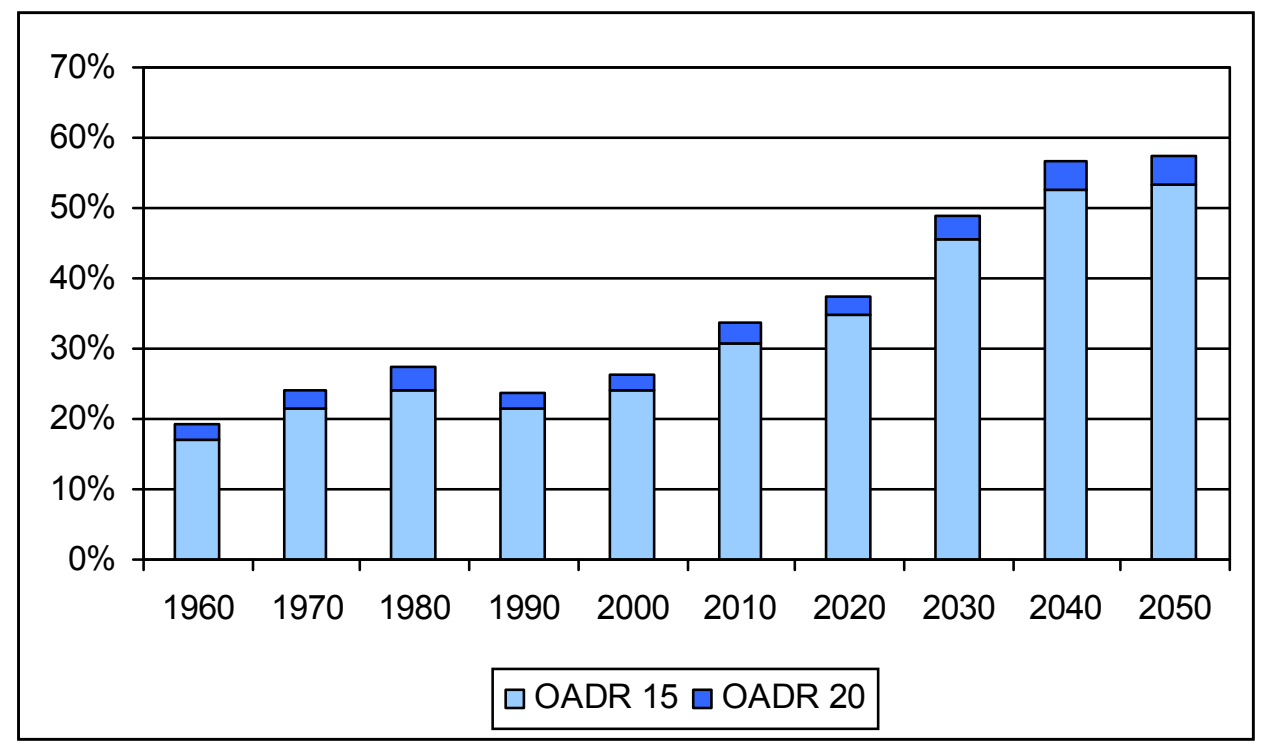

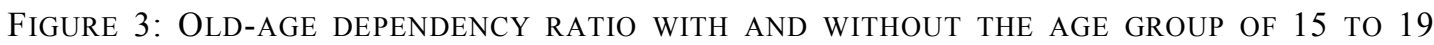
YEAR OLDS FROM 1960 TO 2050

Source: German statistical office for data until 2000 and the Reform Commission on the Sustainability of the Social Security Systems for data projections until 2050.

Labour market development. To what extent these demographic problems will affect the situation of the pension system, depends on the developments of the labour market. According to the projections of the Rürup Commission, the active labour force will decrease by 2.9 million until 2040 (see Figure 4). This rather small decrease, given the demographic development, is due to a presumed fall in unemployment as well as major increases in the participation rates of women and older workers in particular. Productivity growth is predicted to proceed at a rate of $1.5 \%$ per annum, consistent with a $3 \%$ annual nominal increase of wages and an inflation rate of $1.5 \%$.

\footnotetext{
${ }^{42}$ Although it is a good estimate, the OADR does not fully reflect this development, since it neglects the effects of the labour market (See next paragraph).
} 


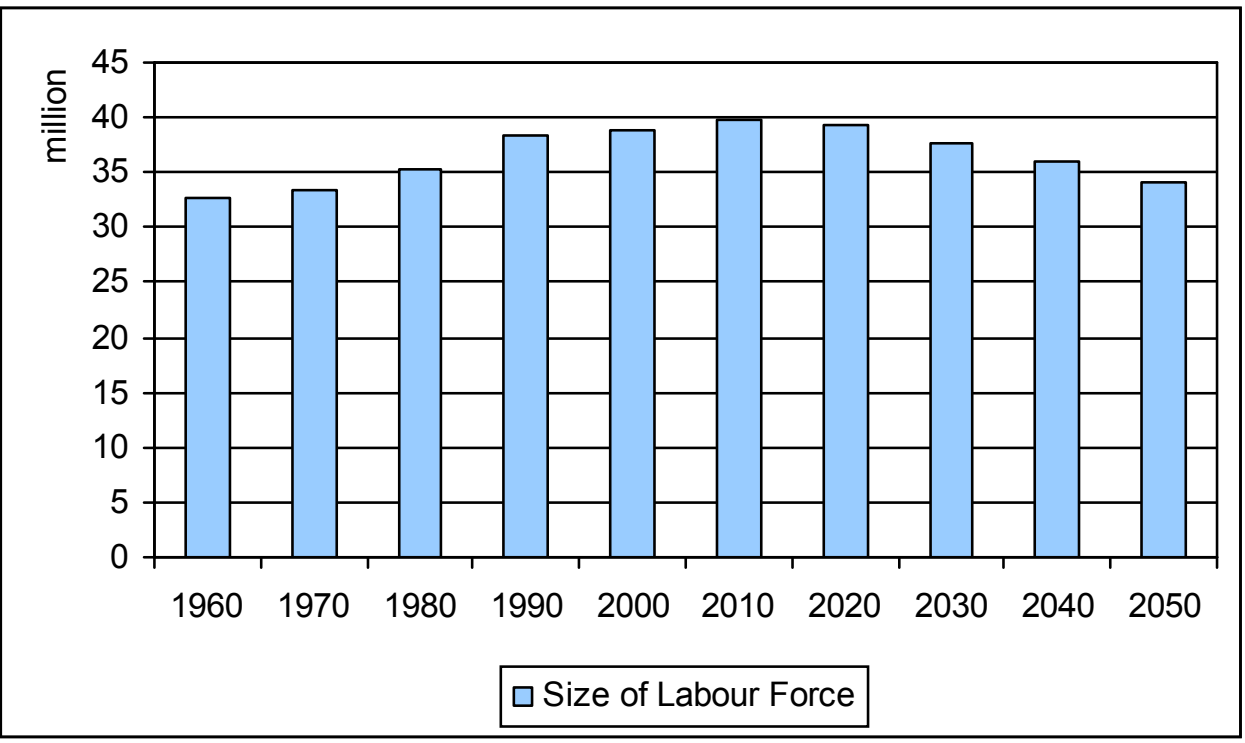

Figure 4: Size of the German LABour ForCe From 1960 TO 2050

Source: German statistical office for data until 2000 and the Reform Commission on the Sustainability of the Social Security Systems for data projections until 2050.

Under these assumptions, the system dependency ratio, which is reflected in the formula of the sustainability factor, can be projected to develop as shown in Figure 5.

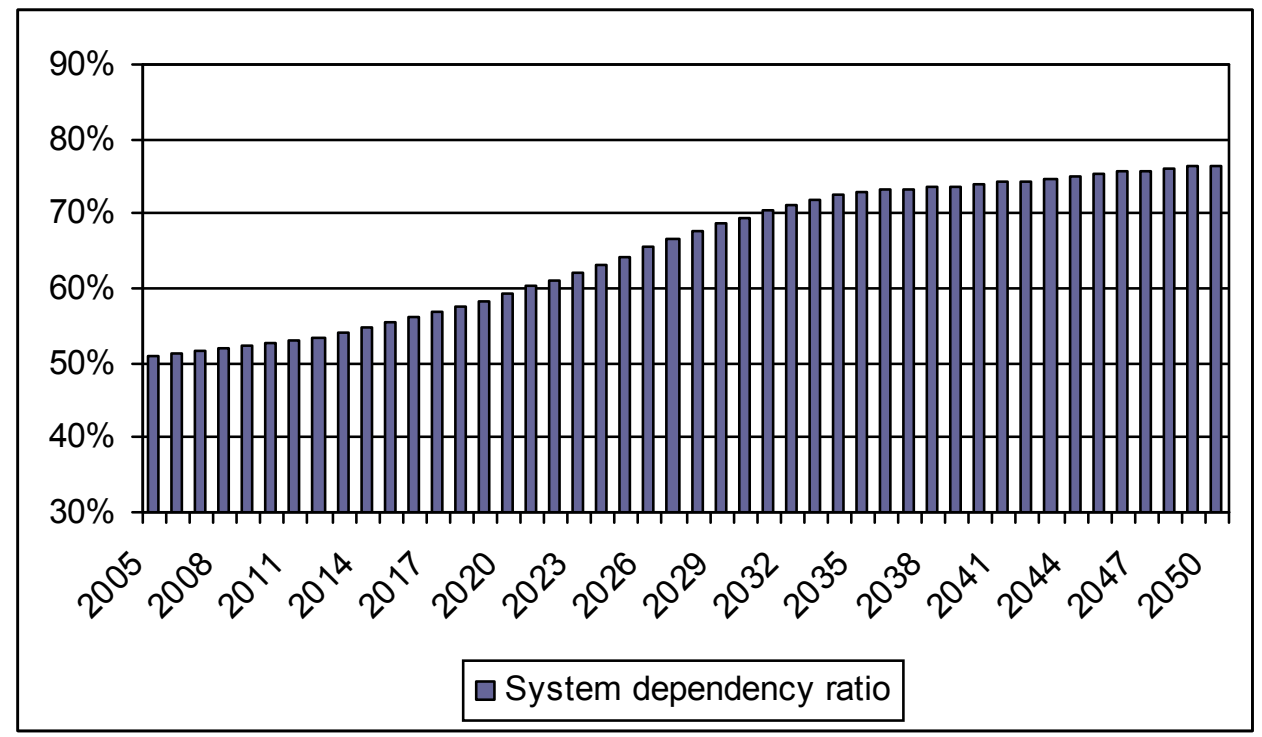

Figure 5: Projected DEVELOPMENT OF THE SySTEM DEPENDENCY RATIO UNTIL 2050

Source: Author's computations based on the demographic and labour market forecasts used by the Reform Commission on the Sustainability of the Social Security Systems (2003). 


\subsection{Future projections based on the status quo}

Given the status quo of the German pension insurance as it was presented in section 3.1 , and given the population and labor market projections presented in section 3.2, how will the public German pension system develop in the future if no further reforms take place? Figure 6 shows the projected development of the contribution rate and the gross pension level for the standard pensioner ${ }^{43}$.

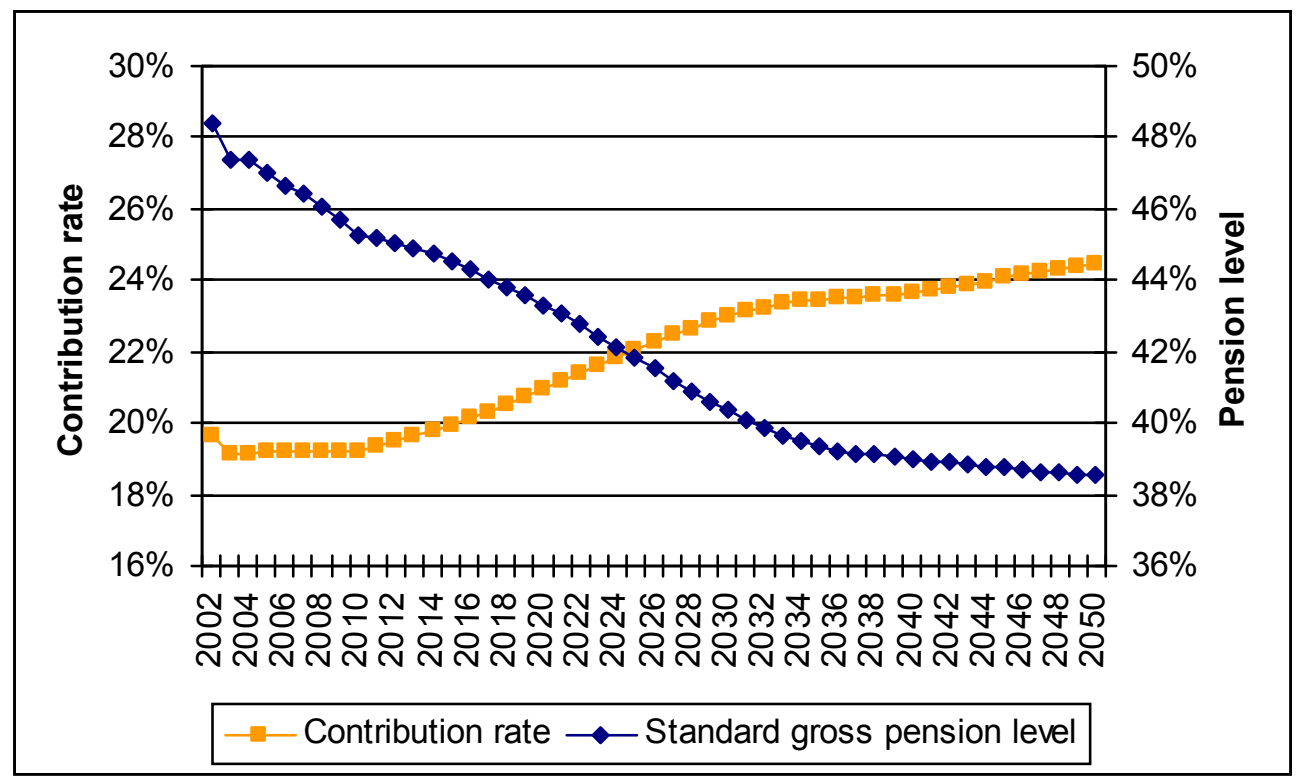

Figure 6: Projected CONTRIBUtion RATES AND GROSS PENSION LEVELS FOR THE CURRENT GERMAN PENSION SYSTEM (REFERENCE SCENARIO)

Source: Author's computations in MEA-PENSIM ${ }^{44}$.

It can be seen that the contribution rate will rise to slightly above $22 \%$ in 2030 and to more than $23 \%$ in 2040 , while gross pension levels will decrease by eight percentage points to around $40 \%$ until $2030 .^{45}$ These projections will serve as the reference scenario for the subsequent simulation analysis in section 3 . In the remaining of this paper, the gross pension level will be used as the applicable measurement for the

\footnotetext{
${ }^{43}$ The standard pensioner is the German reference pensioner, a fictive pensioner who worked for 45 years, always earned the average wage and retired at the statutory retirement age. In the German point system he is thus credited 45 earnings points. In the official German statistics, pension levels are always given for the standard pensioner.

${ }^{44}$ MEA-PENSIM is a simulation program of the German pension system that was developed at the Mannheim Research Institute for the Economics of Aging (MEA) at Mannheim University. For a detailed description of the program, see Wilke (2004). Its basic concept will also briefly be explained in section 4.1 .

${ }^{45}$ Note that the contribution rate here increases a bit more than the projected rate by the German Reform Commission on the Sustainability of the Social Security Systems (2003) of around 22\% until 2030. This is because, for the purpose of this paper, solely the effect of the sustainability factor is considered while the effects of the second important proposed reform measure by the commission, namely a rise in the statutory retirement age from age 65 to age 67 which was implemented under the 2007 pension reform, are neglected.
} 
pension level of the standard pensioner. However, it should be noted that the definition of pension levels in Germany in fact has been changing repeatedly in the past and is likely to soon be revised once more. An overview of the different prevailing definitions is provided in the Appendix.

\section{Economic feasibility}

In the previous section it could be seen that the German pension system already incorporates some of the characteristic features of an NDC system and it was shown how contribution rates and pension levels in this system are projected to develop in the future. If this system was replaced by a genuine NDC system such as described in section 2, what would be the effects on pension levels and the pension insurance's budget? This question is addressed in this section. The subsequent simulation analysis covers the period from 2005 to 2050, assuming that an NDC system replaces the current German public pension system in 2005.

In the following, I first briefly describe how I model the transition of the German public pension system towards an NDC system in section 4.1. Section 4.2 presents the underlying assumptions for my projections. Projection results are illustrated in section 4.3. Last, section 4.4 looks at what happens if the underlying assumptions are altered and points out some exclusive aspects.

\subsection{The model}

The model used for the subsequent simulation analysis is an extension of the MEAPENSIM program that allows calculating the development of contribution rates and pension levels as well as the annual budget development of the German PAYG system on the basis of different reform scenarios. ${ }^{46}$

Basic concept. The program is based on an aggregate, macro level approach. Each year, the number of contributors and pensioners in the system is derived from the underlying labour market and population forecasts and the system's revenues and expenditures are computed according to the development of wages (see labour mar-

\footnotetext{
${ }^{46}$ MEA-PENSIM was developed at the Mannheim Research Institute for the Economics of Aging (MEA) and is frequently being updated in order to reflect recent institutional changes and reform proposals in the German pension system. For the purpose of this simulation analysis, only selective modules of the program are relevant. They will be briefly described below. A detailed description of the remaining modules and their application can be found in Wilke (2004).
} 
ket projections in section 3.2), the contribution rate and existing pension claims. Revenues and expenditures are thereby determined from a cohort perspective. ${ }^{47}$

Revenues. In each year $t$ all cohorts $c$ that are part of the labour force pay a certain amount of contributions $C_{c, t}$ depending on the contribution rate $\tau_{\mathrm{t}}$, the level of average wages $Y_{A v g, t}$ and their respective age-specific income profile $I P_{a \text { : }}$

$$
C_{c, t}=\tau_{t} Y_{\text {Avg }, t} \times I P_{a} .
$$

The age-specific income profile $I P_{a}$ is expressed as a ratio of average wages $Y_{A v g, t}^{48}$ and is the same for all cohorts but varies across age so that in each year $t$ a different income profile $I P_{a=t-c}$ is ascribed to each cohort $c$. Total revenues $R_{t}$ in one year $t$ are thus:

$$
R_{t}=\sum_{c=1}^{c=N_{t}} C_{c, t} \times N_{c, t}
$$

with $\quad N_{c, t} \quad$... number of members of cohort $c$ in year $t$ and

$N_{t} \quad$... here: number of cohorts in year $t$ where members are still in the labour force.

Expenditures. Similarly, total system expenditures $E_{t}$ result from the existing pension claims $P_{c, t}$ of all cohorts $c$ that are part of the pensioner stock:

$$
E_{t}=\sum_{c=1}^{c=M_{t}} P_{c, t} \times M_{c, t}
$$

with $\quad M_{c, t} \quad \ldots$ number of members of cohort $c$ in year $t$ and

$M_{t} \quad \ldots$ here: number of cohorts in year $t$ where members are retired.

How cohort-specific pension claims are determined, whether the contribution rate enters exogenously into the system or is computed endogenously and whether the annual budget constraint holds or not depends on the chosen reform scenario. For the subsequent simulation analysis there are two scenarios that are relevant: the reference scenario that comprises the sustainability factor of the current German pension system and was presented in section 3.3 and the NDC scenario where the current system is replaced by an NDC system such as described in section 2 .

\footnotetext{
${ }^{47}$ Note that for the NDC Scenario, additional incentive effects that result from the automatic adjustment of pension benefits to life expectancy and that lead to later retirement are left out of the subsequent simulation analysis. This was done firstly in order to simplify the analysis and secondly since the underlying labour market forecast already assumes a shift in the mean retirement age by three years. For a thorough study of the size of these effects see Berkel and Börsch-Supan (2003).

${ }^{48} \mathrm{It}$ is assumed that cohorts have reached the average wage income at age 35 and that subsequent wage income will be higher than the average wage. Thus for $a=35$ the income profile is set equal to one, while it is set to values larger than one for $a>35$. This income profile is derived from an empirical study for Western Germany by Fitzenberger et al. (2001).
} 


\subsection{Underlying assumptions}

The demographic and labour market assumptions on which the subsequent simulation analysis is based are those depicted in section 3.2. For the NDC scenario, a number of additional assumptions are necessary in order to specify the system's design. They are presented below.

Contribution rate $\tau_{t}$. As it was explained in section 2.1, the contribution rate enters exogenously into the system. For the simulation analysis it is assumed to develop as it would have if the status quo of the current German pension system was maintained, i.e. as in the reference scenario (recall section 3.3). This way, resulting pension levels for the $N D C$ scenario can be more easily compared to those projected for the reference scenario.

Interest rate $\mathbf{r}_{\mathbf{t}}$ on contributions. Contribution payments accumulated on the notional accounts are assumed to receive annual interest equal to the internal rate of return $^{49}$ of the German PAYG system, i.e. the annual growth rate of the contribution bill, in order to allow for a balanced system in the long-run. Since this rate has been widely fluctuating over the past decades, annual actual nominal values are smoothened by taking a 5 years moving average. ${ }^{50}$ In addition, rates are capped at an absolute nominal level of $6 \%$, so that extremely high rates - as they occurred in Germany in the 1960s and 1970s - are given less weight. The difference between adjusted and actual (nominal and real) values is illustrated in Figure 7.

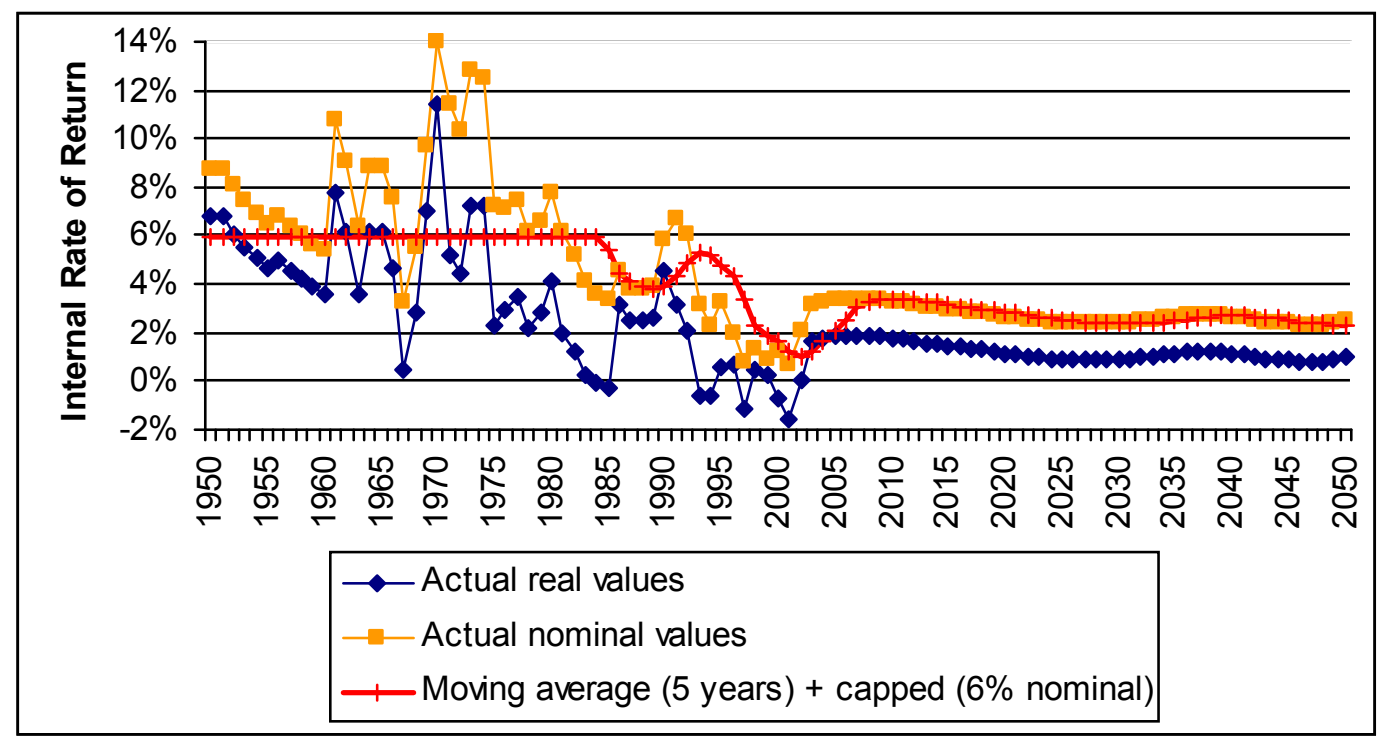

Figure 7: PAST AND FUtURE DEVELOPMENT OF THE INTERNAL RATE OF RETURN

\footnotetext{
${ }^{49}$ Note that the concept of the internal rate of return is a long-term concept. However, for the purpose of this paper, the internal rate of return will be calculated on an annual basis and in nominal terms.

${ }^{50}$ This follows the Italian approach, where the applicable interest rate is also smoothened over 5 years (see footnote 19).
} 
Remaining life expectancy $\mathbf{n}_{\mathbf{B}}$. Life expectancy at the time of retirement is assumed to develop in accordance with the demographic projections presented in section 3.2. This means an increase from 15.8 in 2000 to 19.3 years in 2050 for men and from 19.5 to 23.6 years for women.

Interest rate $\mathbf{r}^{*}$ on notional pension capital. In analogy to the interest accrued on contributions, the internal rate of return is chosen as the applicable interest rate for the annuity calculation. Since the future long-run rate is unknown at the time of the annuity calculation, the rates average value over the last ten years previous to the respective retirement date is used as an approximation of the projected long-run rate, that is to be used if the system shall achieve long-run sustainability. Ten years are necessary if business cycle effects shall be smoothened out. If the rate was averaged over five years only, people would have an incentive to retire earlier in periods of economic slow down and later in periods of economic boom. This might be a valuable policy tool, but shall not be further evaluated at this point.

Indexation factor $\delta$. It is assumed that pensions are indexed to annual nominal wage growth, so that pension benefits remain a constant fraction of wages during the whole retirement period. In accordance with the labour market projections presented in section 3.2 this means an indexing factor $\delta$ equal to $3 \%$ nominal.

Transition. A transition period of 10 years is assumed so that the system is fully established once the German baby-boomers start to retire around 2015. Those pensioners who were already retired before the introduction of the NDC system continue to receive their pensions according to the status quo of the German PAYG system. Those who retire during the transitional phase receive a part of their pension benefits according to the current German system and the other part according to the NDC system, starting at a ratio of "old" to "new" pensions of $90 \%$ in 2005 . Cohorts that retire after this transition period receive their full pension according to the new NDC system. $^{51}$

\subsection{Simulation Results}

Given the same contribution rate development as projected for the reference scenario, which pension levels can be achieved in the NDC scenario? The results are shown below. However, since the annual budget constraint is abandoned in the NDC scenario, it is no longer sufficient to solely consider pension levels. Thus, in a second

\footnotetext{
${ }^{51}$ In principle, this approach follows the transitional rules applied in Sweden. For a description of the Swedish transition process, see e.g. Sundén (2000).
} 
step, additional attention is directed to the development of the pension insurance's budget.

Pension levels. Figure 8 illustrates the development of the cohort-specific pension level at the respective retirement entry in the NDC scenario compared to the development of annual pension levels in the reference scenario. As it was explained in section 2.3, the cohort-specific pension level for a year $t$ only represents the pension level of the cohort that retires in the same year, at the statutory retirement age of 65 . In Figure 8 this means that the 2005 pension level depicts that of the 1940 cohort in its first pension year, while the 2015 pension level corresponds to that of the 1950 cohort in its first pension year. In contrast, in the reference scenario, pension levels in one year $t$ apply to all pensioners, not only to those that retire in that year.

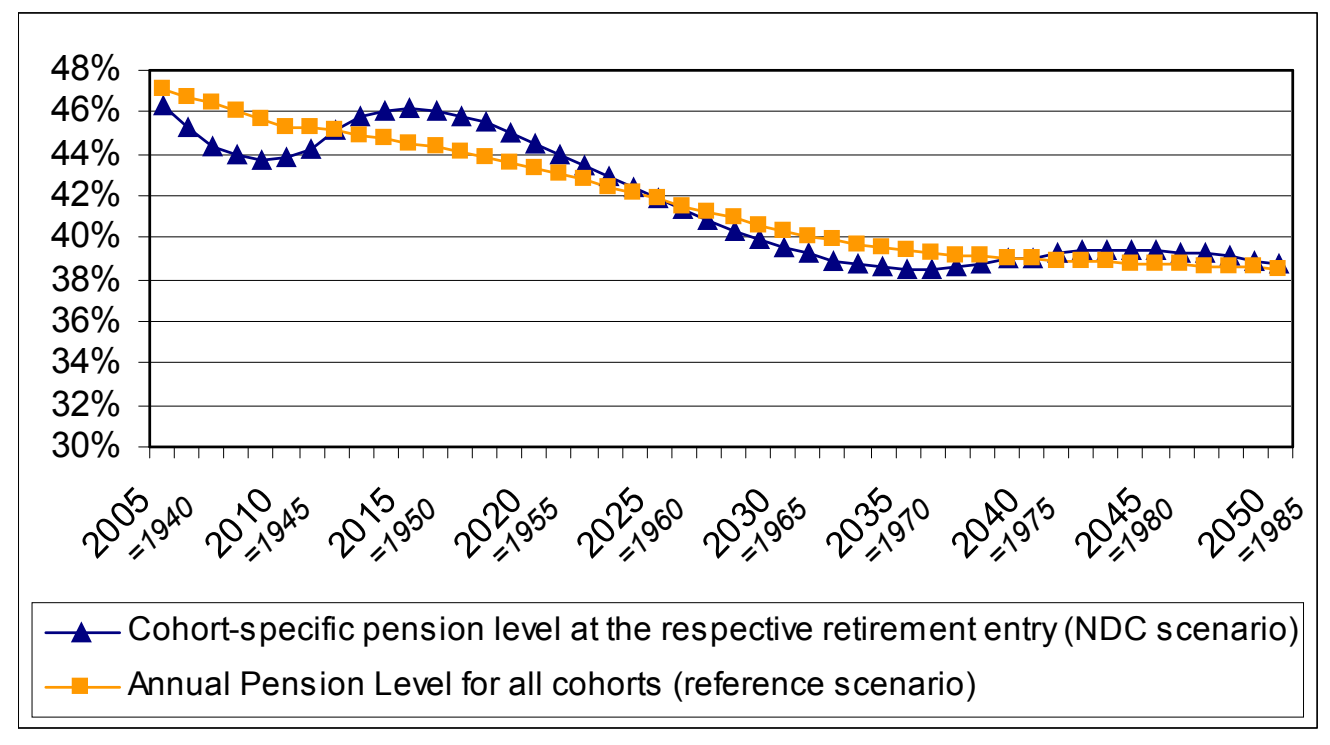

FIGURE 8: COHORT-SPECIFIC PENSION LEVELS IN THE NDC SCENARIO VERSUS PENSION LEVELS IN THE REFERENCE SCENARIO

It can be seen that cohort-specific pension levels in the NDC scenario develop quite close, with a maximum deviation of about $5 \%$, to the pension levels projected for the reference scenario. This astonishes since pension levels in the current German system are determined to decline due to the sustainability factor in the benefit indexation formula, that limits the annual rise in pension levels in favour of a less rising contribution rate under the budget constraint of the system. In contrast, the cohort-specific pension levels in the NDC system do not depend on the short-term budget situation of the pension system, but solely on past values such as the cohort-specific earnings history, applicable interest rates and annuity parameters. 


\section{Cohort-specific pension levels}

Even though internal rates of return have been high in the past compared to today's values (recall Figure 7), pensions for the 1940 cohorts turn out to be lower in the $N D C$ than in the reference scenario. If no transition period was assumed, the pension level of the 1940 cohort would even be lower than that shown in Figure $8 .^{52}$ This can be explained by relatively low contribution rates around $14 \%$ at the start phase of the German PAYG system in the early 1960s, which applies for more than the first fifth of the working period of these cohorts and in addition is weighted more heavily due to effects of compound interest. Cohorts of the 1950s in contrast achieve much higher pension levels under the NDC scenario than under the status quo. They still profit from high internal rates of return, but contributed a significantly higher amount to the pension system due to average contribution rates around 18\%. For the 1960 and 1970 cohorts, the decline of the internal rate of return of the system becomes noticeable in generally lower pension levels. The slight rise in pension levels for the 1980 cohorts can be attributed mainly to the assumed increase in the contribution rate to over $23 \%$ in 2040 .

\section{Benefit indexation}

As it is assumed that pensions in the NDC scenario are indexed to nominal wage growth, the cohort specific pension levels remain a constant fraction of wages over their respective retirement period. This is illustrated for selected cohorts in Figure 9. Note that this is not the case for pension levels in the reference scenario - the decline of pension levels in the reference scenario shown in Figure 8 affects all cohorts equally.

\section{Cohort-specific reform gains and losses}

Given the fact that cohort-specific pension levels in the NDC scenario turn out to be lower for some and higher for other cohorts than their respective pension levels at retirement entry in the reference scenario but that they remain constant over the whole retirement period while pension levels in the reference scenario decline further, what are the cohort-specific reform gains and losses? The answer is given in Figure $10 .{ }^{53}$

\footnotetext{
${ }^{52}$ The effects of the length of the transition period on resulting pension levels are further discussed in the sensitivity analysis in section 4.4.

${ }^{53}$ The reform gains and losses illustrated in Figure 10 were determined by calculating the differences in the rates of return between the reference and the NDC scenario for each cohort. The rate of return was thereby computed as the ratio of total pension benefits to total paid contributions, where the
} 


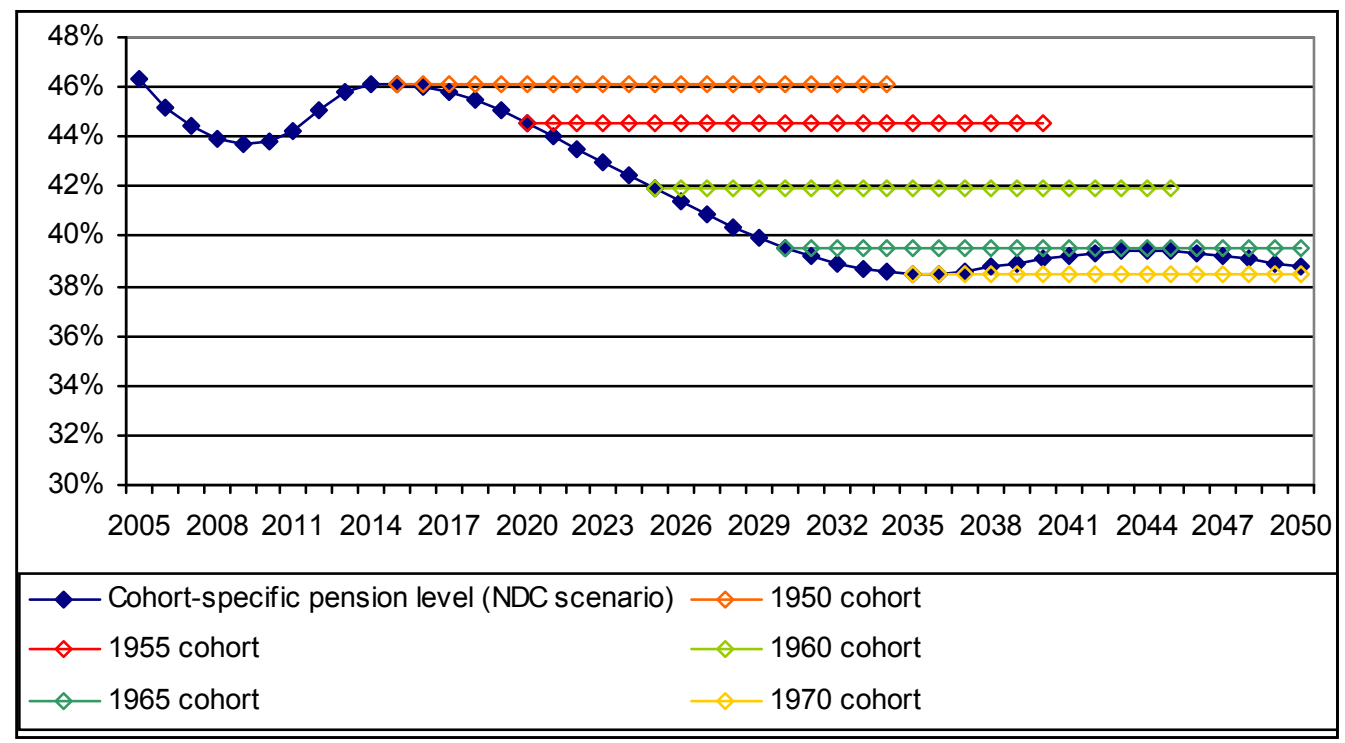

FIGURE 9: COHORT-SPECIFIC PENSION LEVELS IN THE NDC SCENARIO FOR SELECTED COHORTS

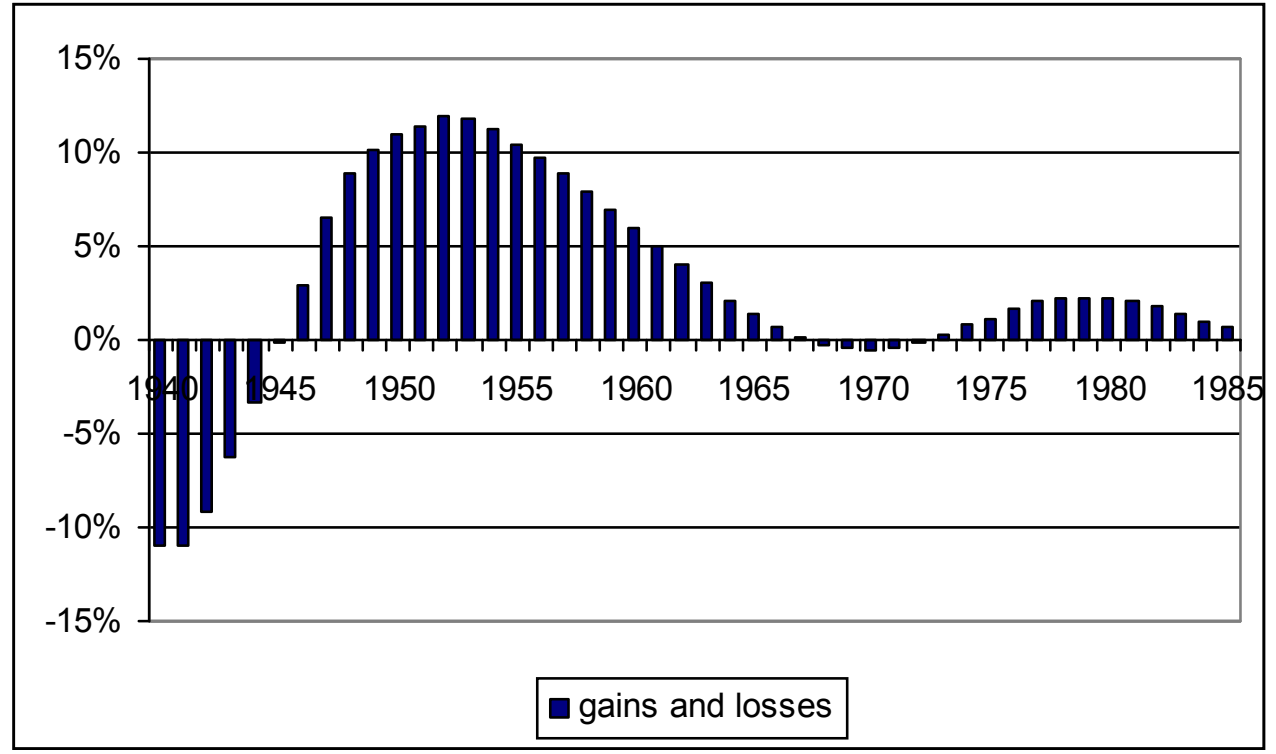

FIGURE 10: REFORM GAINS AND LOSSES FOR AFFECTED COHORTS

As could be expected from the development of pension levels depicted in Figure 8, cohorts of the 1940s loose, while cohorts of the 1950s,1960s and 1980s win. However, in contrast to the results from Figure 8, cohorts from 1946 on until 1967 actually win, even though some of their cohort-specific pension levels are lower than their initial pension levels depicted in the reference scenario. This is the case if it is assumed that their respective retirement period equals the cohort-specific remaining life expectancy at the time of retirement. Over the course of the retirement period, the cohort's return from an initially lower, but stable pension level (recall Figure 9) is

length of the retirement period was set in accordance with the average remaining life expectancy of the respective cohort. 
then higher than that of a initially higher, but declining pension level. Of course, this does not apply to the individual that lives for a shorter period than the average remaining life expectancy for the respective cohort.

\section{“Average" pension levels across all cohorts}

If in the NDC scenario, at one point in time, pension levels across different cohorts vary so significantly from each other, what can be said about the average situation of all retired cohorts in one specific year? Figure 11 shows the development of total cohort pension levels in the NDC system, i.e. the average of all cohort-specific pension levels across cohorts weighted with the respective cohort $\operatorname{size}^{54}$, in comparison to the pension levels in the reference scenario.

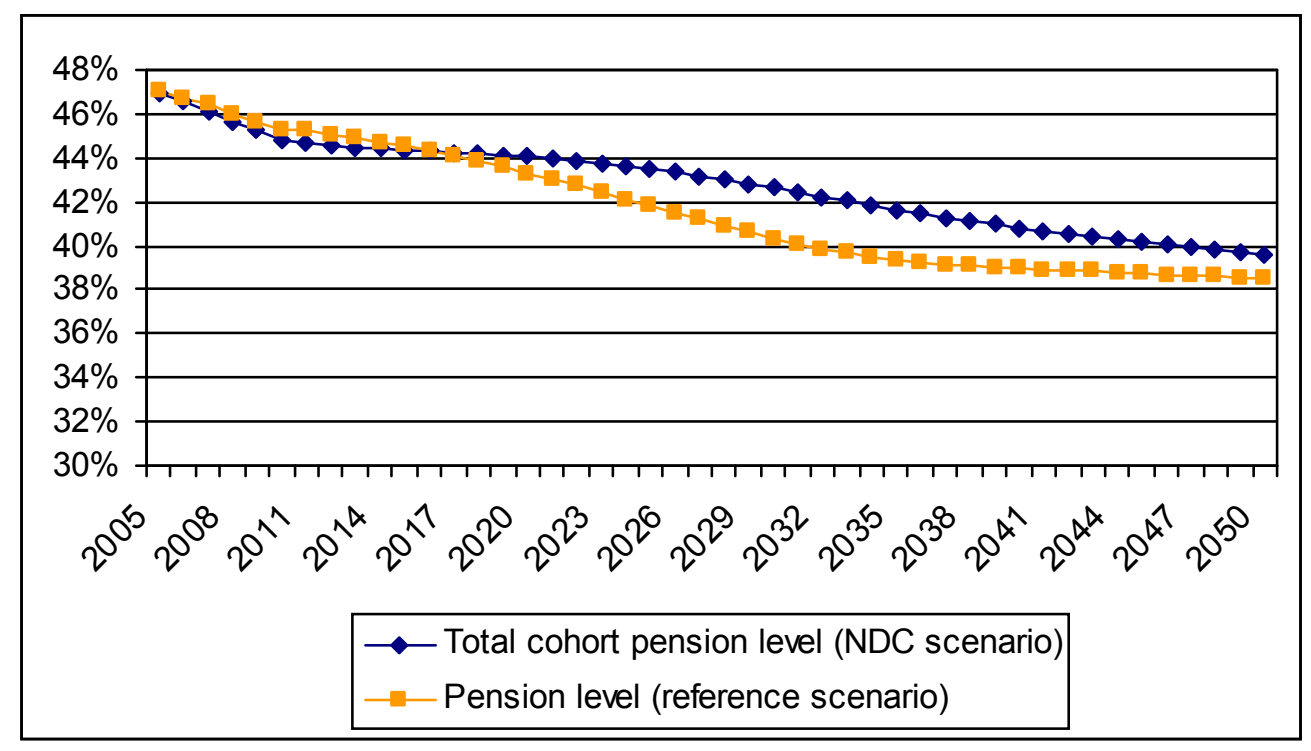

FIGURE 11: TOTAL COHORT PENSION LEVELS IN THE NDC SCENARIOS VERSUS PENSION LEVELS IN THE REFERENCE SCENARIO

In contrast to the development of the cohort-specific pension levels displayed in Figure 8 and Figure 9, total cohort pension levels in the NDC scenario turn out to be continuously higher from 2020 on than pension levels in the reference scenario. This means that in the NDC scenario, the annually changing average standard pensioners across all cohorts achieves a higher pension level in each year than the respective standard pensioner in the reference scenario who is the same for all cohorts and years. However, this does not mean that the same necessarily applies for the average pensioner $^{55}$ in the two scenarios. For example, differences in pension levels between

\footnotetext{
${ }^{54}$ Recall the definition of total cohort pension levels given in section 2.3 .

${ }^{55}$ The average pensioner represents the average across all pensioners, taking account of differences in earnings history, time of retirement entry and age among pensioners.
} 
high-wage and low-wage earners might generally be larger in the NDC scenario than in the reference scenario due to compound interest effects.

Altogether, regarding the development of pension levels, the NDC scenario can be said to be economically feasible. Even though cohort-specific reform losses occur, they are significantly smaller than the gains of the reform. However, this implies a redistribution mainly from the early 1940 cohorts to the baby-boom generation. Given the fact that the baby-boom generation partly induced the demographic challenges the system now has to cope with, this cannot be a political objective.

Budget development. What does the development of pension levels in the NDC scenario displayed in Figure 8 to Figure 11 imply for the budget of the German pension insurance? In contrast to the reference scenario, an annually balanced budget is no longer ensured in the NDC scenario. Instead, the budget develops as illustrated in Figure 10.

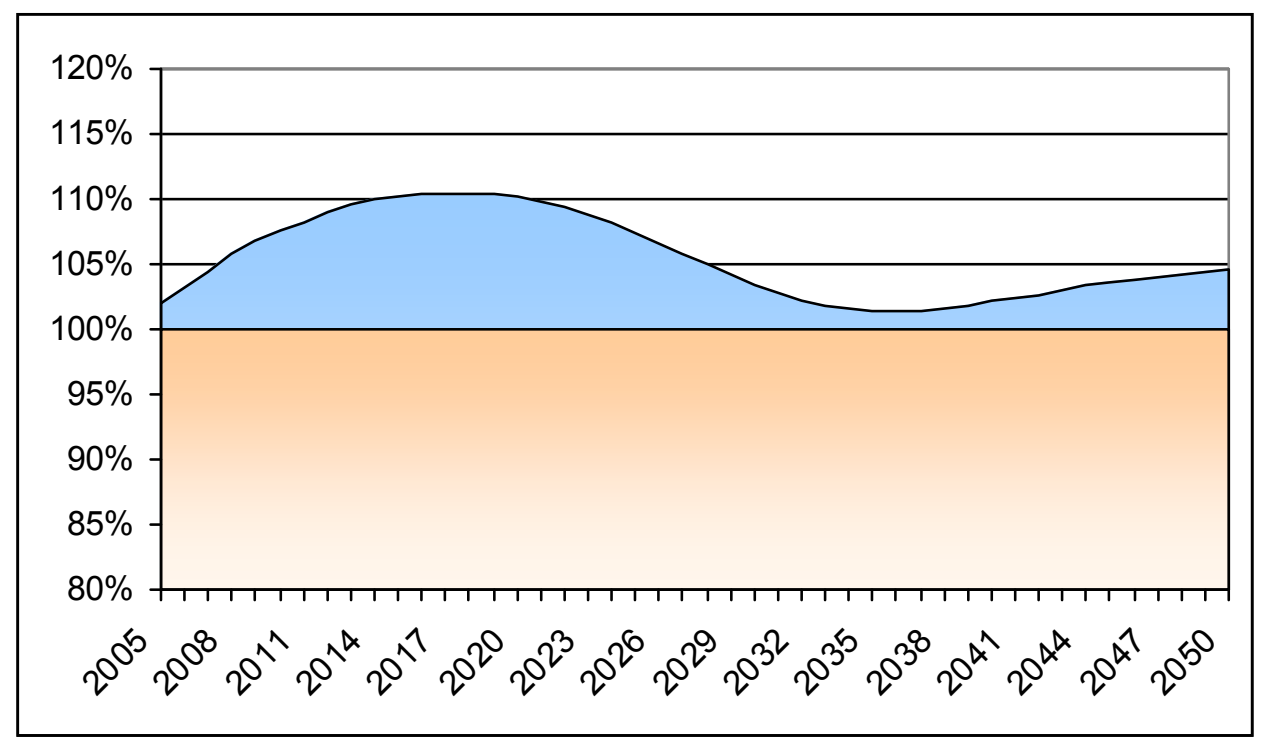

FIGURE 12: BUDGET DEVELOPMENT IN THE NDC SCENARIO

Under the given assumptions, revenues turn out to cover pension expenditures throughout the simulation period. At the beginning of the introduction of the NDC system, pension levels for the first cohorts that retire in the NDC scenario are lower than pension levels projected for the reference scenario - and they stay at this level over the whole retirement period of these cohorts - so that revenues are larger than pension expenditures. For 2015, additional revenues of about 30 billion Euros can be calculated. This amount is equivalent to roughly $40 \%$ of the state subsidies the pension system receives in that year. With the rise in pension levels for the 1950 s cohorts, the surplus in revenues declines as these cohorts start to retire from 2015 on. Once the 1970s cohorts with much lower pension levels retire from 2035 on and 
thereby reduce the average pension level across all cohorts, the amount of additional revenues increases again.

Thus, from a purely budget oriented perspective, the NDC scenario would be feasible for Germany. However, it should be noted, that the budget surpluses only can be accumulated at the expense of specific cohorts whose pension levels in the NDC scenario is lower at the time of retirement than in the reference scenario. But it could also be seen from Figure 10 that some of these cohorts in total still gain from the reform

The question remains, whether the generated revenue surplus also suffices in order to build up the buffer fund that becomes necessary in the NDC scenario in order to cope with short-term budget deficits. According to Heiss (2003), the German pension system could have overcome past recessions with a buffer fund amounting to two months, that is about $17 \%$, of total annual expenditures. In the NDC scenario, this amount would be reached by means of the accumulated surplus revenues by 2010, which would be early enough in order to countervail potential cyclical effects induced by the retirement of the baby-boom generation from 2015 on.

\subsection{Sensitivity analysis}

The results presented above only apply under the assumptions underlying the $N D C$ scenario. What happens if some of these assumptions are altered? A thorough sensitivity analysis was conducted on this question. This section points out some selected aspects. Focus is put on the development of pension levels, while budget effects are deliberately excluded, since they are rather straight forward: higher (lower) cohortspecific pension levels in the NDC scenario have a negative (positive) impact on the overall size of the budget.

Altering the contribution rate $\tau_{t}$. In the literature, it is sometimes claimed that one aim of NDC systems is to stabilize the contribution rate. So far, the simulation analysis only took account of a rising rate, such as in the reference scenario. Figure 13 illustrates the effects on pension levels if the contribution rate instead is fixed at $20 \%$. Note, that in this case, pension levels for the reference scenario are no longer calculated via the benefit indexation formula that comprises the sustainability factor but are determined entirely via the annual budget constraint. In contrast, in the NDC scenario, pension levels are determined precisely the same way as before with the only difference being that different contribution amounts are paid onto the individual accounts. 


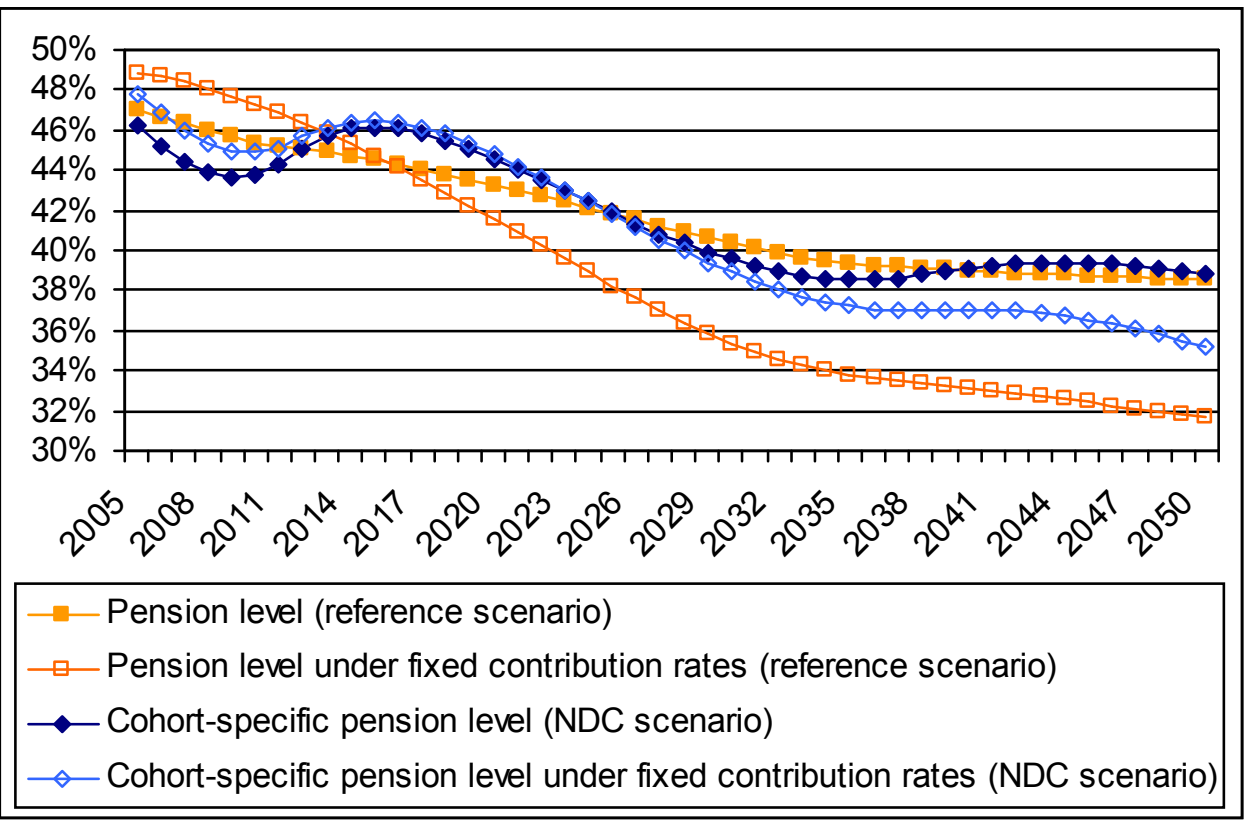

Figure 13: DEVELOPMENT OF PENSION LEVELS FOR A FIXED CONTRIBUTION RATE OF 20\%

For the reference scenario, a fixed contribution rate of $20 \%$ leads to higher pension levels in the short-run as long as the endogenously determined contribution rate would still be lower. As a consequence, in the NDC scenario, cohort-specific pension levels during the transition period also turn out to be higher than before. However, once demographic pressures call for higher contribution rates, pension levels in the reference scenario fall faster than under rising rates. The same effect can be perceived for the NDC scenario from 2030 on. However, while this effect signifies pure intergenerational redistribution in the case of the reference scenario, where the working population pays less contributions thus provoking lower pension levels under the budget constraint of the system, cohorts in the NDC scenario receive lower pension benefits due to the fact that they have acquired lower pension claims as a result of lower contribution rates. In this case, no intergenerational redistribution takes place. Instead, the pension system simply generates less redistribution of income over each individual's life cycle.

Altering the interest rate $\mathbf{r}_{\mathbf{t}}$. In section 2.3 it was stressed that the proper rate of return of an NDC system is the internal rate of return of the system itself. If other interest rates are chosen, the results for the NDC scenario become very different from those presented in section 4. Figure 14 illustrates the development of cohortspecific pension levels in the NDC scenario for alternative interest rates on contributions, i.e. the rate of nominal wage growth and the rate of inflation, that do not take account of changes in demography. It can be seen that, as long as the labour force grows in size, the nominal wage growth rate is smaller than the internal rate of return 
of the system so that pension levels for cohorts that worked during this time period are smaller than if the internal rate of return was used as the applicable interest rate. However, once the labour force declines, the nominal wage growth rate becomes larger than the internal rate of return and higher pension levels are generated for the respective cohorts. Since projected future nominal wage growth is assumed to be $3 \%$ and thus higher than during the nineties, pension levels turn out to be higher for younger cohorts. If interest on the accumulated notional capital is accrued solely according to the inflation rate, resulting pension levels are considerably lower for all cohorts. In this case, no real interest is accrued on the notional capital. Instead, the value of the accumulated capital stock is simply maintained in real values.

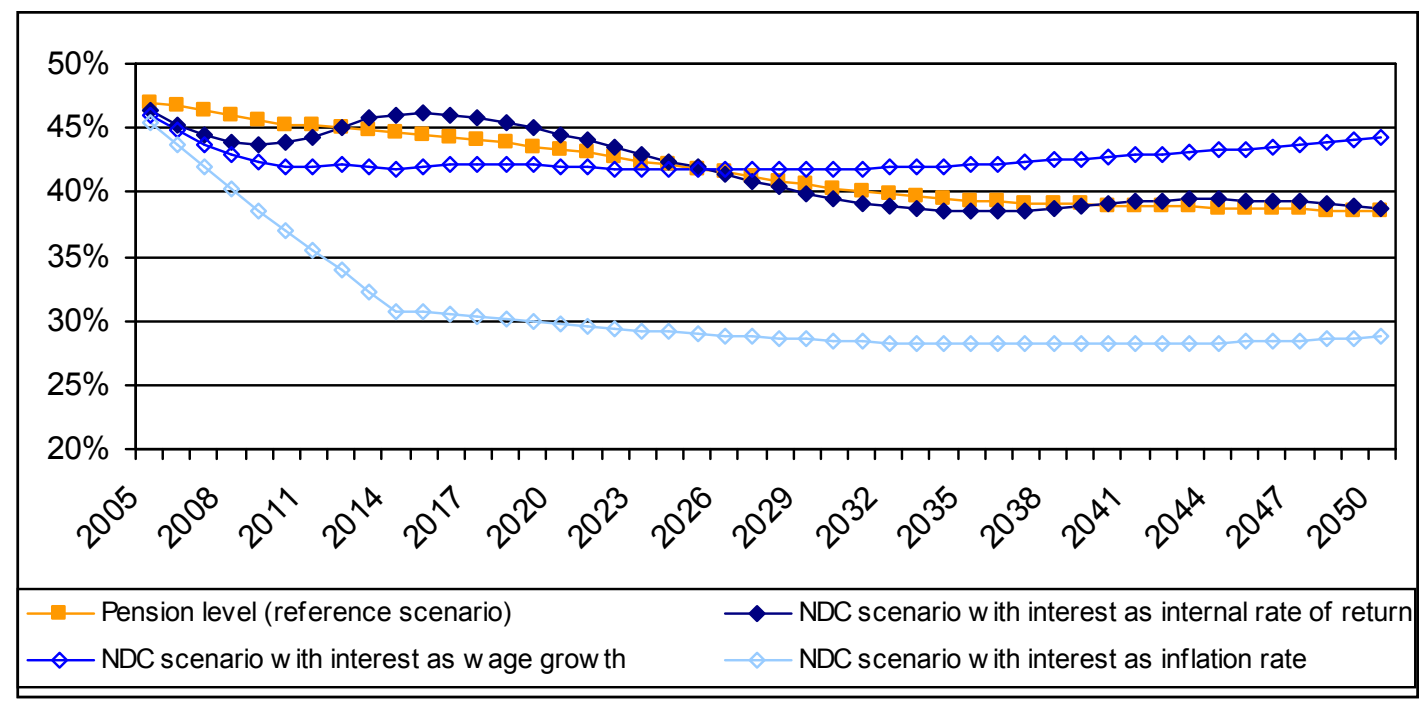

FIGURE 14: PENISON LEVELS IN THE NDC SCENARIO FOR DIFFERENT INTEREST RATES ON CONTRIBUTIONS

Altering the indexing factor $\delta$. So far, pension benefits were assumed to be indexed to nominal wage growth, so that pension levels of specific cohorts remain constant over their respective retirement period (recall Figure 9). Figure 15 shows how cohort-specific pension levels change, if pensions are solely indexed to the inflation rate or are not indexed at all respectively. 


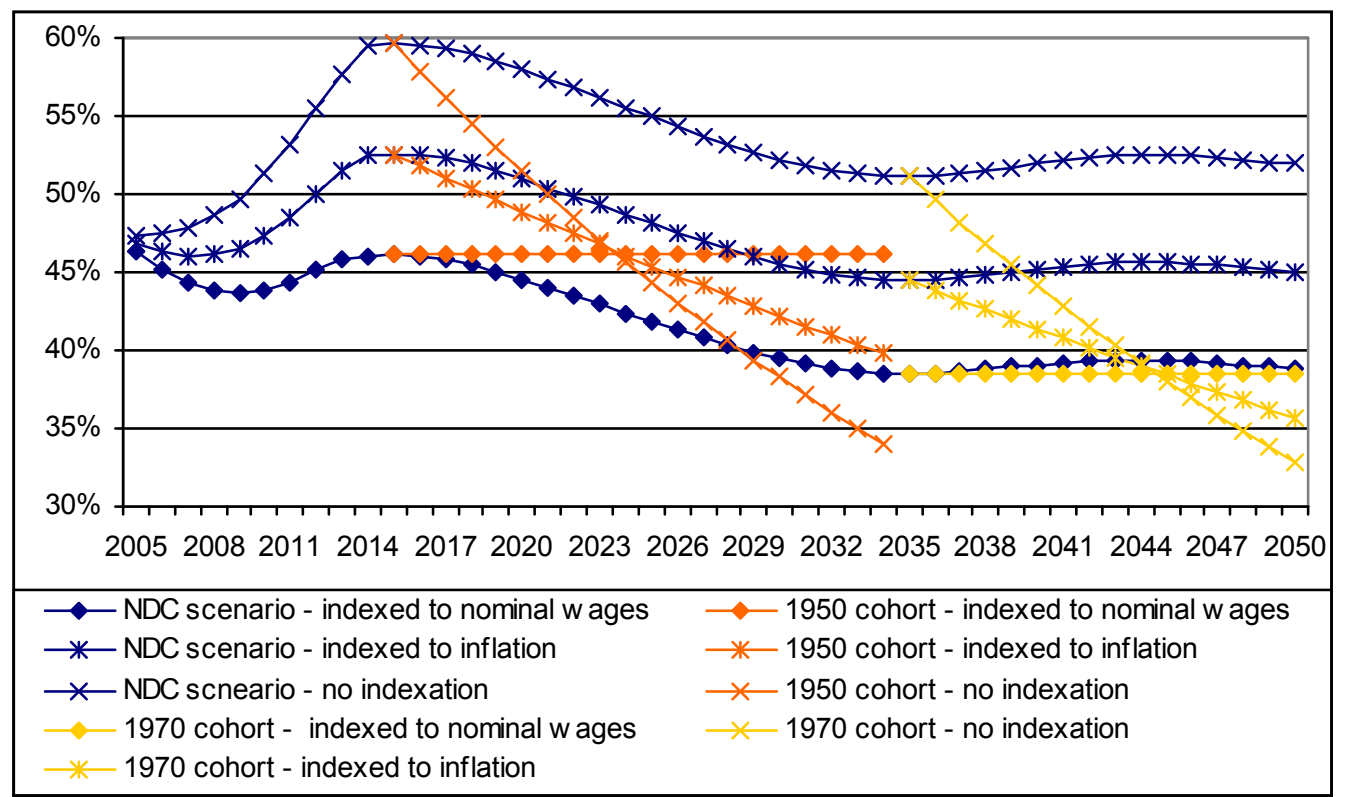

FIGURE 15: TRADE-OFF OF COHORT-SPECIFIC PENSION LEVELS FOR SELECTED COHORTS

In both cases, cohort-specific pension levels at the time of retirement are significantly higher since lower future annual increases have to be anticipated at the time of retirement when the pension annuity is calculated. This trade-off in an NDC system, between higher initial cohort-specific pension levels decreasing over the retirement period and lower pension levels decreasing less or remaining constant in fraction of wages is illustrated more explicitly for the 1950 and 1970 cohort respectively (see again Figure 15). As long as pensions are indexed to inflation, pension benefits in fact remain equal in real values until the end of the retirement period - the resulting gap to a stable pension level throughout the retirement period thus can be ascribed solely to the difference between nominal wage growth and inflation. If pensions are not indexed at all, they significantly loose in purchasing power.

An important question is whether the decision to index pension benefits to a reference rate or not should be left to the individual pensioner or should be made by the state. It should be noted at this point, that this freedom of choice may not always be affordable in an NDC system if debt financing is to be avoided. This is because the accumulated capital in the system is only notional, while the system itself is still run on a PAYG basis. Thus, if no buffer fund is (not yet) available, existing pension claims have to be financed by sources from outside the system. In the case of Germany, if pension benefits of the 1940 cohorts are not indexed and thus would be a lot higher than in the reference scenario, a large deficit would arise while at the same time it would no longer be possible to build up a buffer fund for future potential crises. 
Altering introduction and transition times. For the results in section 4 it was assumed that the NDC system was introduced from 2005 on. Whether the NDC system is introduced earlier or later only affects the cohort-specific pension levels of those cohorts that retire during the transitional period. Generally, later introductions lead to lower cohort-specific pension levels for the respective cohorts (see Figure 16). This is due to the fact that those cohorts with higher pension levels in the NDC scenario than in the reference scenario now fall into the transition period and receive lower pensions than they otherwise would have.

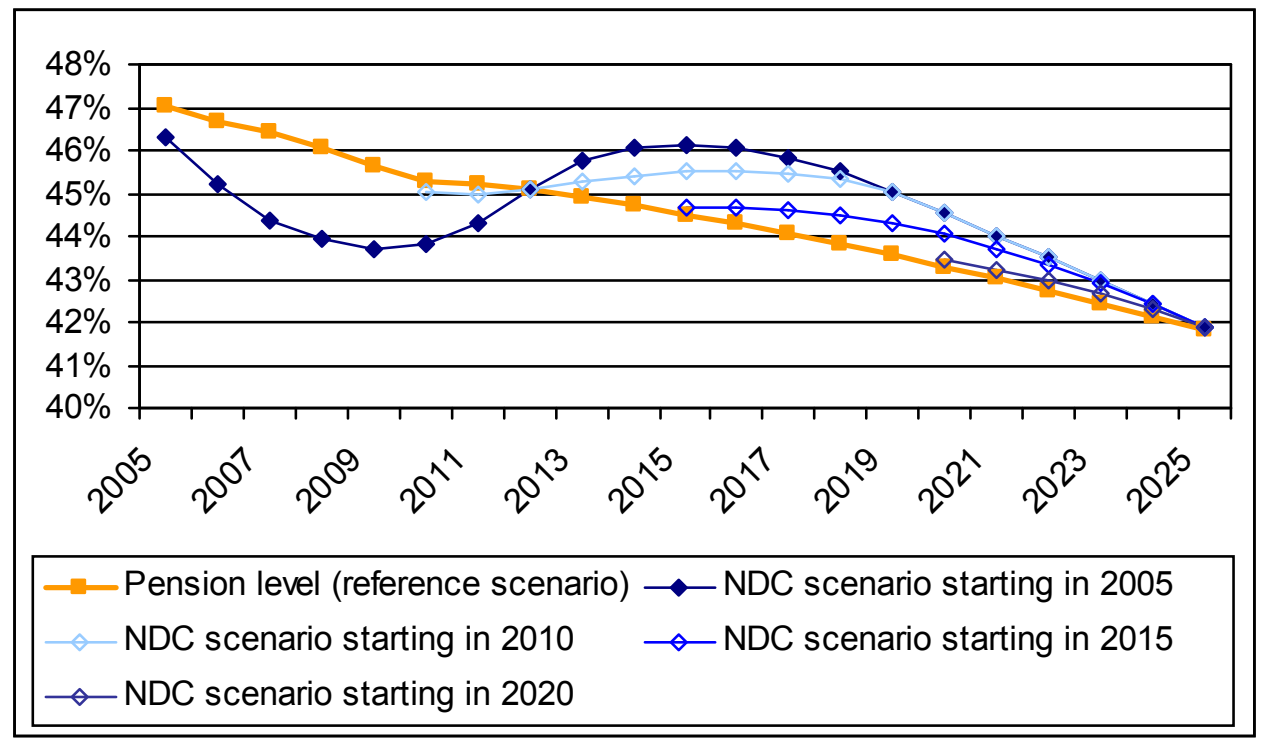

FIGURE 16: TRANSITIONAL PENSION LEVELS IN THE NDC SCENARIO FOR DIFFERENT START YEARS

Similarly, a longer transition period would lead to lower cohort-specific pension levels for those cohorts whose pension is higher in the NDC than in the reference scenario and which then fall into the transition period. On the other hand, for cohorts of the 1940s that receive lower pensions under the NDC scenario, a longer transition period would align their pensions closer along the levels of the reference scenario. In general, it can be found that, for Germany, differences in cohort-specific pension levels across cohorts are levelled off the more the longer the transition period.

Thus, with regard to the size of the reform burden that is carried by the early cohorts of the 1940s in the NDC scenario under the assumptions presented in section 4.2, a later introduction or a longer transition period could be suggestive. Respective simulations show the budget would still remain on surplus, even though the prospective to build up a buffer fund diminishes the later the introduction or the longer the transition period. However, this simulation analysis is based on the rather optimistic demographic and labour market forecasts presented in section 3.3. If the labour market develops differently in a way that even more pressure is exerted on the pension 
system, a delay of the reform or an extension of the transition period may make it impossible to carry out the necessary measures in sufficient time.

\section{Conclusion}

This paper looked at the question whether the introduction of an NDC system could be a feasible reform alternative for the German PAYG pillar. The simulation analysis conducted in the main part of this paper indeed showed that a German NDC system would provide adequate pension levels above, equal or only slightly below those that can be forecasted for the standard pensioner under the present German PAYG pension system that comprises the sustainability factor. However, in terms of affordability it was shown that an NDC system may require large buffer funds which are currently not available under the current German pension system and can only be built up under very restrictive assumptions.

Furthermore, the distribution of pension income among cohorts would be very different than under the current system, favoring cohorts of the 1950s and 1960s while disadvantaging cohorts of the 1940s that paid lower contribution rates to the system, and cohorts from the 1970s which are affected by the decreasing growth rate of the contribution bill. This clearly is a result that cannot be politically motivated. It illustrates quite clearly the differences between the German time-oriented and the cohortoriented NDC system where cohort-specific pension levels are largely driven by the past and forecasted demographic and labor market development as well as a country's historic and future economic performance. ${ }^{56}$

However, in one point the NDC system still better ensures long-term sustainability than the German system: benefits are automatically actuarial fairly adjusted to the retirement age -- accounting for future developments in life expectancy. In the German system, in contrast, the adjustment factors are not linked to the future development of life expectancy. This remains a soft spot of the German PAYG pension system, especially in the light of continuous further increases in life expectancy. ${ }^{57}$

\footnotetext{
${ }^{56}$ Note that there are also additional redistributive effects in an NDC system. In the earnings points based German system, pension levels are proportional to the amount of accumulated earnings points. In the NDC system in contrast, this is no longer the case as pension claims that are collected early during the working life profit from a compound interest effect from which flat income profiles profit more than steep income profiles.

${ }^{57}$ See e.g. Clemens (2006\} for an illustration of the past and projected future rises in life expectancy and past and projected future retirement ages.
} 
Altogether, it should be clear that an NDC system does not solve the demographic problems but that it simply copes with them in a different way than conventional PAYG system. In contrast to funded pension systems for example, there is no additional money created in an NDC system. The existing capital is simply distributed differently, minimizing the intergenerational redistribution across generations typical for conventional PAYG systems. Thus, an NDC system can only offer an optimisation of the first pillar but does not replace the necessity to supplement the public pension system by a funded second and third pillar in order to prepare for the future demographic changes. 


\section{References}

Aaron, H. (1966): The Social Insurance Paradox, Canadian Journal of Economics and Political Science XXXII (3), 371-374.

Barr, N. (2003): Notional defined contribution pensions: Mapping the terrain, Paper Presented at the World Bank and Swedish Social Insurance Board Conference on NDC Pensions, Sandhamn, September 28-30, 2003.

Berkel, B., and A. Börsch-Supan (2003): Pension Reform in Germany: The Impact on Retirement Decisions, MEA Discussion Paper 31-03, Mannheim Research Institute for the Economics of Aging, Mannheim University.

Börsch-Supan, A. (2000): Incentive Effects of Social Security on Labour Force Participation: Evidence in Germany and Across Europe, Journal of Public Economics 78, 25-49.

Börsch-Supan, A. ( 2004): What are NDC Pension Systems? What do they bring to Reform Strategies?, MEA Discussion Paper 42-03, Mannheim Research Institute for the Economics of Aging, Mannheim University.

Börsch-Supan, A., A. Reil-Held and C. Wilke (2003): Der Nachhaltigkeitsfaktor und andere Formelmodifikationen zur langfristigen Stabilisierung des Beitragssatzes zur GRV, Sozialer Fortschritt 11-12, 275-284.

Börsch-Supan, A., and C. Wilke (2004): The German Public Pension System: How it Was, How it Will Be, NBER Working Paper No. 10525, National Bureau of Economic Research.

Brooks, S. and R. Weaver (2003): Lashed to the mast?: The Politics of Notional Defined Contribution Pension Reforms, Paper Presented at the World Bank and Swedish Social Insurance Board Conference on NDC Pensions, Sandhamn, September 28-30, 2003.

Brugiavini, A. and V. Galasso (2004): The social security reform process in Italy: where do we stand?, Journal of Pension Economics and Finance, July 2004.

Chłoń, A., M. Góra and M. Rutkowski (1999): Shaping Pension Reform in Poland: Security through Diversity, Social Protection Discussion Paper Series No. 9923, World Bank, Washington, D.C.

Chłoń, A. and M. Góra. (2003): The NDC system in Poland - assessment after 5 years, Paper Presented at the World Bank and Swedish Social Insurance Board Conference on NDC Pensions, Sandhamn, September 28-30, 2003.

Clemens, J. (2006). Anmerkungen zur geplanten Anhebung des gesetzlichen Rentenalters. Wirtschaftsdienst (3), $163\{167$.

Disney, R. (1999): Notional Accounts as a Pension Reform Strategy: An Evaluation, Social Protection Discussion Paper Series No. 9928, World Bank, Washington, D.C. 
Fitzenberger, B., R. Hujer, T. McCurdy und R. Schnabel (2001): Testing for uniform wage trends in West-Germany: A cohort analysis using quantile regressions for censored data, Empirical Economics 26, 41-86.

Fox, L., and E. Palmer (1999): Latvian Pension Reform, Social Protection Discussion Paper Series No. 9922, World Bank, Washington, D.C.

Franco, D. and N. Sartor (2003): Notional Defined Contribution in Italy: Unsatisfactory Present, Uncertain Future, Paper Presented at the World Bank and Swedish Social Insurance Board Conference on NDC Pensions, Sandhamn, September 28-30, 2003.

German Reform Commission on the Sustainability of the Social Security Systems (2003): Final Report, Bundesministerium für Gesundheit und Soziale Sicherheit, Berlin.

Gronchi, S. and R. Aprile (1998): The 1995 Pension Reform: Equity, Sustainability and Indexation, Labour 12 (1), 67-100.

Heiss, F. (2003): Wie groß soll die Schwankungsreserve der gesetzlichen Rentenversicherung sein? MEA Discussion Paper 33-03, Mannheim Research Institute for the Economics of Aging, Mannheim University.

Holzmann, R. and R. Palacios (2001): Individual Accounts as Social Insurance: A World Bank Perspective, Social Protection Discussion Paper Series No. 0114, World Bank, Washington, D.C.

Lindbeck, A. and M. Persson (2003): The Gains from Pension Reform, Journal of Economic Literature, Vol. XLI, 74-112.

Ohsmann, S. ,U. Stolz and R. Thiede (2003): Rentenabschläge bei vorgezogenem Rentenbeginn: Welche Abschlagssätze sind "richtig"?, Die Angestelltenversicherung 4, 2003.

Palmer, E. (2000): The Swedish Pension Reform Model: Framework and Issues, Social Protection Discussion Paper Series No. 0012, World Bank, Washington, D.C.

Palmer, E. (2003): Conversion to NDC - Issues and Models, Paper Presented at the World Bank and Swedish Social Insurance Board Conference on NDC Pensions, Sandhamn, September 28-30, 2003.

Samuelson, P. A. (1958): An Exact Consumption Loan Model of Interest with or without the Social Contrivance of Money, Journal of Political Economy 66, 467-482.

Schnabel, R. (1998): Rates of Return of the German Pay-As-You-Go Pension System, Finanzarchiv 55(3), 374-399.

Settergren, O. (2001): The Automatic Balance Mechanism of the Swedish Pension System, Wirtschaftspolitische Blätter 4, 2001.

Settergren, O. (2001): Two Thousand Five Hundred Words on The Swedish Pension Reform, Paper Presented at the Workshop on Pension Reform at the German Embassy, Washington D.C., July 12, 2001.

Settergren, O. (2003): The Rate of Return of Pay As You Go Pension Systems, Paper Presented at the World Bank and Swedish Social Insurance Board Conference on NDC Pensions, Sandhamn, September 28-30, 2003. 
Sundén, A. (2000): How will Sweden's New Pension System Work?, Issue in Brief No. 3-00, Center for Retirement Research, Boston College.

Valdés-Prieto, S. (2000): The Financial Stability of Notional Account Pensions, Scandinavian Journal of Economics 102(3), pp.395-417.

Verband Deutscher Rentenversicherungsträger (VDR) (2002): Rentenversicherung in Zeitreihen, DRV-Schriften 22, Frankfurt am Main.

Wilke, C. (2004): Ein Simulationsmodell des Rentenversicherungssystems: Konzeption und ausgewählte Anwendungen von MEA-PENSIM, MEA Discussion Paper 48-04, Mannheim Research Institute for the Economics of Aging, Mannheim University.

World Bank (1994): Averting the Old-Age Crisis: Policies to Protect the Old and Promote Growth, New York, Oxford University Press. 


\section{Appendix}

\section{Pension level concepts in the German public pension system}

In Germany, pension levels in the official statistics are typically displayed for the socalled standard pensioner. The standard pensioner is a fictitious person who worked for 45 years, always earned the average wage income and retired at the statutory retirement age of 65 . He is thus credited 45 earnings points $\mathrm{EP}_{\text {Strd }}$, which multiplied by the current pension value $\mathrm{PV}_{\mathrm{t}}$ in a specific year $\mathrm{t}$ gives his annual pension income (see equation 8 in section 3.1). The pension level $\mathrm{PL}_{t}$ describes the value of this pension income relative to the average wage income $Y_{A v g, t}$ of the covered labour force in the same year $\mathrm{t}$ :

$$
P L_{t}=\frac{E P_{\text {Strd }} \times P V_{t}}{Y_{A v g, t}}
$$

The pension level is to be distinguished from the replacement level that describes the individual pension income relative to the last or average individual wage income during the working life. Pension levels can be expressed in gross or net terms and may comprise additional aspects. In the following, the different concepts that have been applied in Germany are briefly explained.

Net pension level. This measurement was used during the nineties. The net pension level describes the relation between the pension income net of taxes and net average wage income. Hitherto, only the interest portion of the accrued pension benefit was subject to taxation while wage income was fully taxable. As a consequence, net pension levels were distinctively higher than gross pension levels (around 70\% compared to roughly $50 \%$ ).

\section{Modified gross pension level accounting for supplementary Riester pension con-}

tributions. The Riester reform modified the definition of the net pension level. From 2001 on not only taxes, but also the recommended contributions to the statesubsidized private Riester pension were subtracted from the average net wage income, so that net pension levels turned out to be higher than according to the conventional definition (projected values for 2040 of $67 \%$ instead of around 63\%). 
Net pension level before tax. Since from 2005 on, pension income will step by step become subject to deferred taxation, a universal pension level that is equally applicable to all pensioners, will no longer exist. Instead, during the transition to deferred taxation for pension income, pension levels will vary across cohorts depending on the respective degree of fully taxable pension income of each cohort. The tax adjusted net pension level accounts for this by specifying an annual pension level that is solely applicable to the standard pensioner of the cohort that retires the same year.

Gross pension level. In view of scheduled tax relieves for the labour force as well as the planned introduction of deferred taxation for pension income, the pension level definition was changed to gross terms in the context of the Rürup Commission's work in 2003. The gross pension level describes the relation between gross pension income and gross average wage income (see formula above). It is considerably lower than the net pension level since differences in taxation and labour fringe costs are not taken into account. 


\section{Discussion Paper Series}

Mannheim Research Institute for the Economics of Aging Universität Mannheim

To order copies, please direct your request to the author of the title in question.

\begin{tabular}{|c|c|c|c|}
\hline Nr. & Autoren & Titel & Jahr \\
\hline $153-07$ & $\begin{array}{l}\text { Axel Börsch-Supan } \\
\text { Christina B. Wilke }\end{array}$ & $\begin{array}{l}\text { Szenarien zur mittel- und langfristigen } \\
\text { Entwicklung der Anzahl der Erwerbspersonen } \\
\text { und der Erwerbstätigen in Deutschland }\end{array}$ & 07 \\
\hline $154-07$ & $\begin{array}{l}\text { Alexander Ludwig, } \\
\text { Alexander Zimper }\end{array}$ & $\begin{array}{l}\text { A Parsimonious Model of Subjective Life } \\
\text { Expectancy }\end{array}$ & 07 \\
\hline $155-07$ & $\begin{array}{l}\text { Alexander Zimper, } \\
\text { Alexander Ludwig }\end{array}$ & Attitude polarization & 07 \\
\hline $156-08$ & $\begin{array}{l}\text { Florian Heiss, } \\
\text { Daniel McFadden, } \\
\text { Joachim Winter }\end{array}$ & $\begin{array}{l}\text { Mind the Gap! Consumer Perceptions and } \\
\text { Choices of Medicare Part D Prescription Drug } \\
\text { Plans }\end{array}$ & 08 \\
\hline $157-08$ & Wolfgang Kuhle & Demography and Equity Premium & 08 \\
\hline $158-08$ & $\begin{array}{l}\text { Axel Börsch-Supan, } \\
\text { Tabea Bucher-Koenen, } \\
\text { Anette Reil-Held, } \\
\text { Christina Wilke }\end{array}$ & $\begin{array}{l}\text { Zum künftigen Stellenwert der ersten Säule im } \\
\text { Gesamtsystem der Alterssicherung }\end{array}$ & 08 \\
\hline $159-08$ & $\begin{array}{l}\text { Tabea Bucher-Koenen, } \\
\text { Christina Benita Wilke }\end{array}$ & $\begin{array}{l}\text { Zur Anhebung der Altersgrenze: Eine Simulation } \\
\text { der langfristigen Auswirkungen auf die gesetz- } \\
\text { liche Rentenversicherung bei unterschiedlichem } \\
\text { Renteneintrittsverhalten }\end{array}$ & 08 \\
\hline $160-08$ & Mathias Sommer & $\begin{array}{l}\text { Imputation and Harmonisation of Income, } \\
\text { Consumption, Savings and Wealth Data from } \\
\text { the German Income and Expenditure Survey }\end{array}$ & 08 \\
\hline $161-08$ & Karsten Hank & Generationenbeziehungen im alternden Europa & 08 \\
\hline $162-08$ & $\begin{array}{l}\text { Axel Börsch-Supan, } \\
\text { Karsten Hank, } \\
\text { Hendrik Jürges, } \\
\text { Mathis Schröder } \\
\end{array}$ & $\begin{array}{l}\text { Longitudinal Data Collection in Continental } \\
\text { Europe: Experiences from the Survey of Health, } \\
\text { Ageing and Retirement in (SHARE) }\end{array}$ & 08 \\
\hline $163-08$ & Martin Salm & Job loss does not cause ill health & 08 \\
\hline $164-08$ & $\begin{array}{l}\text { Martin Salm, Daniel } \\
\text { Schunk }\end{array}$ & $\begin{array}{l}\text { The role of childhood health for the inter- } \\
\text { generational transmission of human capital: } \\
\text { Evidence from administrative data }\end{array}$ & 08 \\
\hline $165-08$ & Christina Benita Wilke & $\begin{array}{l}\text { On the feasibility of notional defined contribution } \\
\text { systems: The German case }\end{array}$ & 08 \\
\hline
\end{tabular}

